\title{
TRABALHO NOS EXTREMOS: UMA REFLEXÃO SOBRE TRABALHO E GUERRA FRIA UTILIZANDO TÉCNICAS DE RPG NO ENSINO MÉDIO INTEGRADO
}

\author{
Luiz Fabricio de Oliveira Mendes ${ }^{1}$ \\ Lorena Temponi Boechat ${ }^{2}$ \\ Lerice de Castro Garzoni ${ }^{3}$
}

\begin{abstract}
RESUMO
Tratando-se da educação profissional brasileira, longos são os debates sobre ser utilitária ou emancipadora. Essa discussão envolve a reflexão sobre o Ensino Médio Integrado. Como a formação omnilateral, unindo teoria e prática, efetiva-se ou não nesse currículo, principalmente na integração das Ciências Humanas à área técnica dos cursos? Nesta pesquisa em Educação Profissional e Tecnológica (EPT), procurou-se, além de analisar esse panorama em turmas do IFSULDEMINAS Campus Poços de Caldas, elaborar como produto educacional um RPG (Role-Playing Game) para apresentar aos alunos os diferentes modelos de organização industrial. Também se objetivou explorar as relações históricas e políticas dessas modalidades de trabalho com a Guerra Fria (1945-1989), inserindo a reflexão dentro da disciplina de História - contribuindo ao debate político da atualidade. Como fundamentação ao uso do RPG como ferramenta educacional, utilizou-se a teoria sociointeracionista de Lev Vygotsky (1896-1934).
\end{abstract}

Palavras-chave

Educação Profissional e Tecnológica. História. Ensino Técnico. Ciências Humanas.

\section{WORK AT THE EXTREMES: A REFLECTION ON WORK AND THE COLD WAR USING RPG TECHNIQUES IN INTEGRATED HIGH SCHOOL}

\begin{abstract}
Concerning Brazilian professional education, long debates exist about it being utilitarian or emancipatory. This discussion involves reflection on Integrated High School. How does omnilateral learning, uniting theory and practice, take effect in this curriculum, mainly in the integration of Human Sciences to the technical content of these courses? In this research at Professional and Technological Education (EPT), it was sought, in addition to analyzing this panorama in classes of IFSULDEMINAS - Campus Poços de Caldas, to elaborate a RPG (Role-Playing Game) as educational product to present students with the different models of industrial organization. It also aimed to explore the historical and political relationships of these work models with the Cold War (1945-1989), bringing the reflection to the discipline of History - contributing to the current political debate. As a basis for the use of RPG as an educational tool, Lev Vygotsky's (1896-1934) socio-interactionist theory was used.
\end{abstract}

Keywords: Professional and Technological Education. History. Technical Education. Human Sciences.

\footnotetext{
${ }^{1}$ Estudante pesquisador no IFSULDEMINAS - Campus Poços de Caldas.

E-mail: fabricio_wayne@yahoo.com.br

${ }^{2}$ Professora orientadora no IFSULDEMINAS - Campus Poços de Caldas.

E-mail: lorena.boechat@ifsuldeminas.edu.br.

${ }^{3}$ Professora co-orientadora no IFSULDEMINAS - Campus Poços de Caldas.

E-mail: lerice.garzoni@ifsuldeminas.edu.br. 


\title{
TRABAJO EN LOS EXTREMOS: UNA REFLEXIÓN SOBRE EL TRABAJO Y LA GUERRA FRÍA UTILIZANDO TÉCNICAS DE ROL EN LA ESCUELA SECUNDARIA INTEGRADA
}

\begin{abstract}
RESUMEN
En el caso de la educación profesional brasileña, hay largos debates sobre ser utilitario o emancipatorio. Esta discusión implica una reflexión sobre la Escuela Secundaria Integrada. ¿Cómo se hace efectiva o no la capacitación omnilateral, uniendo teoría y práctica, en este currículo, principalmente en la integración de las Ciencias Humanas al área técnica de los cursos? En esta investigación en Educación Profesional y Tecnológica (EPT), se buscó, además de analizar este panorama en las clases de IFSULDEMINAS - Campus Poços de Caldas, elaborar como producto educativo un juego de rol (RPG) para presentar a los estudiantes los diferentes modelos de organización industrial También tuvo como objetivo explorar las relaciones históricas y políticas de este tipo de trabajo con la Guerra Fría (1945-1989), insertando la reflexión dentro de la disciplina de la Historia, contribuyendo al debate político actual. Como base para el uso de RPG como herramienta educativa, se utilizó la teoría socio-interaccionista de Lev Vygotsky (1896-1934).
\end{abstract}

Palabras clave: Educación Profesional y Tecnológica. Historia. Educación Técnica. Ciencias Humanas.

\section{INTRODUÇÃO}

Há décadas, são realizadas no Brasil discussões sobre a educação profissional, focadas em seus modelos, concepções teóricas e, acima de tudo, a quem e a que serviriam. Conforme descreve Nosella (2011), desde a Constituição de 1988 há o embate entre os vieses neoliberal (destinado, mais diretamente, à profissionalização de mão de obra ao mercado) e "politécnico" (conceito o qual, ainda que etimológica e semanticamente disputado, refere-se a um ensino omnilateral e emancipador, destinado a formar o ser humano integralmente, numa concepção marxista) desse ensino.

A LDB 9394/1996 (BRASIL, 1996), tentando abarcar ambas as propostas ao estabelecer o ensino técnico concomitante e subsequente ao médio, acabou, com isso, separando a educação profissional da propedêutica, reforçando o aspecto apenas utilitário da primeira. O Decreto 5154/2004 (BRASIL, 2004) propôs-se a realizar novas concessões à proposta emancipadora ao instituir o modelo de Ensino Médio Integrado ao Técnico. Se por um lado tal medida mostrou-se imenso avanço em direção ao princípio omnilateral, trazendo à realidade as bases filosóficas pelas quais se lutou ao longo de um debate de décadas, por outro, ao manter as modalidades concomitante e subsequente coexistentes à integrada, procurou, como espécie de "concessão" à sua implementação, preservar os interesses anteriores de formação de mão de obra (PEREIRA JÚNIOR; MOREIRA, 2013) e, assim, a dualidade escolar: ensino generalista precário à maior parte da população e aprimorado a uma REVISTA ENSAIOS E PESQUISA EM EDUCAÇÃO E CULTURA - 2020. 1 / vol . 5 - n.8 
pequena parcela privilegiada; enquanto a formação ao trabalho mantém o viés instrumental e é "dada" às classes populares para integrá-la à produção ao sistema.

Agravando o cenário, a MP 746/2016 (BRASIL, 2016), que instituiu a reforma do ensino médio em todo país, caminha no sentido de priorizar a formação profissional imediata (com seus "itinerários formativos") e o enxugamento dos conteúdos de formação geral, consolidando o predomínio da proposta neoliberal e utilitária.

Nesta pesquisa, procurou-se partir da seguinte problemática: até que ponto o ensino profissionalizante ofertado nos Institutos Federais (IFs), em sua modalidade Integrada ao Ensino Médio, oferece aos alunos conhecimentos sobre o mundo do trabalho e uma inserção crítica nas relações de produção, de modo que possam identificar as tecnologias, discursos e princípios ideológicos que perpassam a profissionalização em nossa sociedade? Mais ainda, a quem serve o discurso de considerar o trabalho, como entendido na concepção materialista histórica, superado, ao ponto de não mais poder se falar numa classe trabalhadora, e todas as dinâmicas, muitas vezes exploratórias, que a envolvem? (ANTUNES, 1999).

O escopo de nossa análise foi focado nas turmas do Ensino Médio Integrado ao Técnico do IFSULDEMINAS - Campus Poços de Caldas. No tocante à almejada formação omnilateral, decidiu-se por analisar o quanto as disciplinas de Ciências Humanas integram-se ou não à área técnico-profissional dos cursos no campus, tornando esses conhecimentos específicos apenas "fins em si mesmos", ou abordados de modo socialmente relevante ao papel que o estudante assumirá no mundo do trabalho. Nesse quesito, preocupou-se em analisar como os próprios alunos identificam essa inter-relação: se inerente ao próprio estudo dos conteúdos técnicos, pontual em determinados momentos de interconexão durante as aulas, ou tomada como não existente.

Considerando as bases já expostas, o Ensino Médio Integrado deve ser orientado pela integração do currículo para além de uma justaposição de matérias propedêuticas e técnicas ou uma mera "interdisciplinaridade" conectando conteúdos de algumas disciplinas enquanto elas permanecem, em si, desconectadas - tomadas pela "dinâmica da totalidade" e só se dispondo a integrar o que é particular (FRIGOTTO; ARAÚJO, 2015). Identificou-se, no caso analisado, uma deficiência de tornar as Ciências Humanas relevantes, assim como efetivamente integradas, ao Ensino Médio Integrado. Esse dado mostrou-se de grande importância ao posterior desenvolvimento da pesquisa.

Em meio a essa discussão, destacamos também um elemento político, mais diretamente relacionado às Ciências Humanas, do qual o ensino integral, voltado à plena formação intelectual e material do ser, não pode se desvincular (GRAMSCI, 2001). Assiste-se 
Mendes, L. F. de O.; Boechat, L. T.; Garzoni, L. de C.

no Brasil a um crescente processo de polarização ideológica (principalmente após as manifestações de junho de 2013), o debate político entre concepções de "direita" e "esquerda" tomando conta do espaço público e influenciando não apenas os processos eleitorais, mas a formação das visões de mundo (BRUGNAGO; CHAIA, 2014).

Centrada na construção do "medo do outro", a polarização leva à problemática sobre trabalho ser associada ao "comunismo". Nisso, qualquer crítica e reflexão acerca da produção no modelo capitalista são tomadas como "perigo vermelho". A própria dimensão política do trabalho é perdida, deixando-se de enxergar como diferentes concepções sobre o mesmo tornam-se fundamentos dos diferentes sistemas socioeconômicos. A discussão tornou-se entrincheirada como na Guerra Fria, e conhecer os fundamentos de um pensamento contrário passou a equivaler a "defender o bloco rival", numa nova geopolítica bipolar. Mas, se o debate político atual readquiriu os contornos da Guerra Fria, propôs-se nesta pesquisa, além da reflexão sobre o trabalho, justamente retornar a esse período para desmistificar o ato de realizar essa reflexão.

Notou-se que essa correlação de temas inclusive já existia no livro didático de História utilizado nos terceiros anos do Ensino Médio Integrado da instituição quando a pesquisa foi realizada (VAINFAS, 2016, p. 239-241), comparando o Toyotismo ocidental ao Taylorismo soviético na fase final da Guerra Fria e como seus respectivos desdobramentos econômicos influenciaram a geopolítica internacional.

Assim, partindo dos conteúdos concernentes aos temas trabalhados no Ensino Médio Integrado ao Técnico dos IFs, e buscando seu aprofundamento, pretendeu-se elaborar e aplicar, nos cursos integrados de Eletrotécnica e Informática do IFSULDEMINAS - Campus Poços de Caldas, um produto educacional na forma de um sistema de RPG (Role-Playing Game - Jogo de Interpretação de Papéis), tendo como cenário o período histórico da Guerra Fria, para estimular entre os alunos o debate sobre os dois sistemas político-econômicos da época (Capitalismo, representado pelos EUA, e Socialismo, pela URSS) e, atrelada a estes, a questão sobre diferentes modelos de trabalho industrial - motivando a reflexão sobre a própria formação dos alunos e contribuindo para o conhecimento sobre as técnicas modernas que, atreladas a objetivos produtivos mais amplos, além de suas contradições, fundamentam o mundo profissional no qual serão inseridos. 
Os RPGs ${ }^{4}$ são um jogo de mesa em que um dos participantes, denominado "mestre" ou "narrador", conduz uma história e descreve o cenário, desafios e circunstâncias que a estruturam, enquanto os "jogadores" interpretam personagens como em um teatro, realizando jogadas de dados para superar os obstáculos preparados pelo mestre na narrativa. Cada jogador possui acesso a uma ficha de jogo, em que as informações sobre seu personagem, de habilidades a recursos disponíveis, são sistematizadas, orientando as jogadas de dados e, desse modo, o resultado das ações realizadas. Trata-se, em suma, de uma história criada em conjunto entre mestre e jogadores, centrada em cooperação do grupo para a superação de desafios, dentro de um parâmetro comum de regras e um ambiente ficcional no qual os personagens atuarão - sendo, necessariamente, construção coletiva (VASQUES, 2008).

Por ser capaz de construir, através de sua narrativa, outras realidades, o RPG constitui grande reserva de ferramentas simbólicas para o ensino, possibilitando, através da vivência por meio dos personagens interpretados pelos jogadores, a apreensão de uma série de conceitos sobre outros contextos sociais - e, no escopo deste projeto, mundos do trabalho que poderiam não ser bem delineados numa aula expositiva comum. Nisso incluem-se as peculiaridades de distintos sistemas de produção industrial, como o Fordismo ou o Toyotismo (ALVES, 1999), melhor apreendidas através da interpretação de papéis de trabalhadores dos respectivos sistemas, com as habilidades e subjetividades requeridas.

Mais ainda, como tais concepções de trabalho coexistiram na Guerra Fria, durante a qual, nos anos 1970, a reestruturação do capital levou ao advento do Toyotismo no Ocidente e gradativa diminuição do Fordismo, caracterizando o fim da "Era de Ouro" do sistema (HOBSBAWN, 1995); enquanto na União Soviética, desde a Revolução de 1917, predominou um sistema de fábricas baseado no Taylorismo (o qual, em sua origem nos EUA, levou ao próprio Fordismo), sistematização herdada do Capitalismo que, dentro de diversas contradições, acreditou-se poder servir aos propósitos do trabalhador emancipado, como analisaram Arbix (1997), Augustin (2015) e Lazagna (2017). De modo similar a como o Toyotismo, no Ocidente, levou a uma fragmentação da consciência de classe (ANTUNES, 1999), análises tais quais a de Donald Filtzer (FILTZER, 1996) apontam como o Taylorismo,

\footnotetext{
${ }^{4}$ Sua grande difusão teve início com o lançamento do sistema "D\&D" (Dungeons and Dragons - Masmorras e Dragões, criado por Gary Gygax e Dave Arneson) em 1974, consistindo num conjunto de cenário e regras para se jogar RPG numa ambientação de fantasia medieval, a prática faz-se presente na cultura das mais variadas maneiras, desde a ampliação de cenários e sistemas como Storytelling, GURPS, 3D\&T e muitos outros (VASQUES, 2008).
} 
Mendes, L. F. de O.; Boechat, L. T.; Garzoni, L. de C.

na URSS, serviu igualmente a uma diluição dessa consciência ao desmobilizar a classe operária politicamente, gerando uma atomização do trabalho com agudas consequências produtivas ao sistema socialista. Como se encarava a contradição entre trabalhadores que procuravam reter maior controle sobre sua atividade e uma burocracia disposta a instrumentalizar os meios de produção? Ou então, como era tomada a questão do esforço de milhões de trabalhadores ser direcionado à construção de armas nucleares, o clima de terror e paranoia movendo toda uma indústria? (BARNET apud HOBSBAWN, 1995).

Se o aluno vivenciar essas e outras situações durante uma sessão de RPG, através da interpretação de papéis delimitada pelo cenário e as regras, pode se situar melhor na maneira como alguém do contexto estudado pensaria e agiria, o que torna o jogo ferramenta relevante para a assimilação de outras realidades.

O mestre/narrador da sessão de RPG, no caso o professor, exerce a importante função de "andaime de aprendizagem" para os alunos-jogadores, pois, coordenando a narrativa, acaba apresentando conceitos, cenários, personagens e modos de interação correspondentes à ambientação do jogo que os estudantes ainda não conseguiriam assimilar sozinhos, fornecendo as ferramentas para que ao longo da partida possam pouco a pouco interpretar por seus próprios meios a realidade apresentada. Dentro da concepção sociointeracionista de Lev Vygotsky (VYGOTSKY, 1991, 2001, 2010, 2012), o caráter cooperativo do RPG estimula a interação social e cultural para o desenvolvimento cognitivo - com os jogadores, trabalhando em grupo entre seus pares, utilizando a linguagem ${ }^{5}$ para chegar a consensos sobre as decisões tomadas pelos jogadores dentro do jogo; passando pelo auxílio mútuo - os jogadores com maior facilidade para analisar os desafios e compreender a dinâmica do jogo (entender a lógica das jogadas de dados, ajudar os demais a encontrarem informações requeridas em suas fichas de personagem etc.) auxiliando os demais nessas tarefas, dentro de suas respectivas Zonas de Desenvolvimento Proximal (ZDP). Isso auxiliaria os alunos a desenvolverem sociabilidade, influenciando e imitando uns aos outros e acelerando a resolução de problemas.

Reproduzir imaginativamente uma atividade pautada em regras pelo jogo também faz perceber as regras da atividade real que acabam ignoradas quando vivenciadas no cotidiano: "O que na vida real passa despercebido pela criança torna-se uma regra de comportamento no

\footnotetext{
${ }^{5}$ E acabando também por trabalhar com suas diferentes variações, já que numa mesa de RPG existem as conversas "normais", "meta-jogo", efetuadas entre os jogadores para discutirem entre si as soluções de problemas encontrados na narrativa, darem dicas uns aos outros e até fazerem brincadeiras; e a "fala dos personagens", baseada na interpretação dos mesmos de acordo com o cenário e as características de cada papel gerando diferentes tipos de mediação. 
Mendes, L. F. de O.; Boechat, L. T.; Garzoni, L. de C.

brinquedo" (VYGOTSKY, 1991, p. 63). Tratando de um RPG sobre mundo do trabalho, podemos considerar até que ponto trabalhadores encenarem seu cotidiano através de um jogo tornaria explícitas, através da interpretação de seus papéis, as regras definidoras de suas relações de produção - até mesmo desnaturalizando contradições ou formas de exploração. Essas relações, expostas pelo jogo, comporiam novos significados em suas consciências, influenciando suas ações futuras nessas mesmas relações produtivas.

No contexto desta pesquisa, visa-se justamente verificar tal relação entre alunos do Ensino Médio Integrado ao Técnico preparando-se ao posterior ingresso no mercado de trabalho, delineando e colocando em discussão aspectos das atividades produtivas até então não abordados em sua formação ou prévia vivência profissional, proporcionando postura crítica perante as contradições existentes e a capacidade de buscar e criar condições de trabalho com viés emancipador.

\section{METODOLOGIA}

\section{Considerações sobre a amostra}

A premissa inicial desta pesquisa foi utilizar um questionário semiestruturado para analisar os conhecimentos e percepções prévios dos alunos do IFSULDEMINAS - Campus Poços de Caldas quanto aos distintos sistemas de trabalho industrial (como Fordismo e Toyotismo), a Guerra Fria e perspectivas de trabalho após a conclusão do Ensino Médio Integrado; além de verificar qual o grau de relevância social enxergado nessa atividade, se os estudantes consideram-se possuindo alguma posição política formada (com exposição opcional desta) e, finalmente, qual o grau de articulação percebido entre as Ciências Humanas e a área técnica/profissionalizante dos cursos. Os dados obtidos por meio deste questionário embasaram a elaboração do produto educacional na forma do RPG, procurando trabalhar com maior especificidade os pontos mais pertinentes observados.

Ao total, catorze alunos participaram da pesquisa, sendo divididos em dois grupos de jogo com sete alunos cada. Destes, quatro eram do terceiro ano (apenas do curso Integrado a Informática) e dez do primeiro ano (oito do curso Integrado a Eletrotécnica, e dois do Integrado a Informática). A reduzida amostragem de alunos do terceiro ano e a ausência de alunos do segundo ano deram-se devido à maioria destes necessitar do período da tarde,

\footnotetext{
${ }^{6}$ Em sua obra, o autor dá o exemplo de duas irmãs que resolvem brincar justamente de "serem irmãs", encenando a realidade. Isso faz com que, em seus papéis durante a brincadeira, reproduzam todos os comportamentos que acreditem serem definidores de uma convivência entre irmãs, por mais que os naturalizem, agindo sem percebê-los, na relação real. 
quando as sessões de jogo foram realizadas, para cumprir suas horas de estágio - situação não vivenciada pelos alunos ingressantes. Considerando apenas os cursos (independente dos anos), houve, assim, oito alunos analisados do curso Integrado a Eletrotécnica, e seis do curso Integrado a Informática.

Os grupos de jogo foram estabelecidos de modo a um deles unir alunos do terceiro e primeiro anos (quatro da Informática e três da Eletrotécnica, respectivamente, o qual chamaremos de "Grupo 01"), para analisar o RPG como ferramenta de estímulo à ZDP com base nas teorias de Vygotsky. O outro grupo integrou somente alunos dos primeiros anos (cinco da Eletrotécnica e dois da Informática, denominado "Grupo 02"), para uma melhor observação do desempenho dos estudantes no jogo quando reunidos somente entre outros de sua mesma série.

\section{Resultado dos questionários preliminares}

Nos questionários preliminares, os alunos foram orientados, nas perguntas sobre conhecimentos específicos, a descreverem como classificavam o que sabiam dos temas (em "muito", "mediano", "pouco" ou "nada") e, se possível, resumir o que sabiam sem precisar consultar outras fontes.

Primeiramente, questionou-se sobre o Taylorismo/Fordismo.

GRÁFICO 1 - Qual é seu conhecimento sobre os sistemas de trabalho industriais do Taylorismo e Fordismo, ou seja, como a indústria funcionava no começo do século XX?

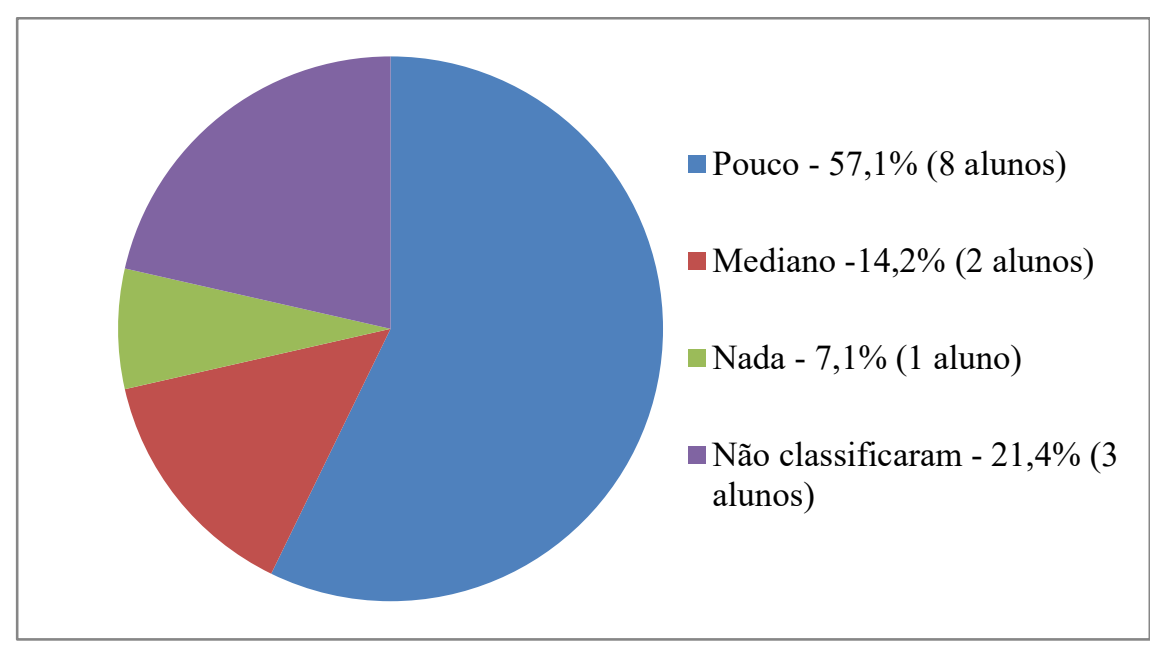

Fonte: Autores.

Alguns dos alunos que classificaram seu saber descreveram o que sabiam, outros somente descreveram: no Grupo 01, dois alunos (14,2\%, não descreveram seu saber, sendo um do $3^{\circ}$ Informática e um do $1^{\circ}$ Eletrotécnica) mencionaram o objetivo de maximizar o lucro 
Mendes, L. F. de O.; Boechat, L. T.; Garzoni, L. de C.

pela produção em linha de montagem, e um aluno (7,1\%, saber "mediano", $1^{\circ}$ Eletrotécnica) destacou a divisão em tarefas.

No Grupo 02, as respostas se alternaram entre método de produção em esteira (um aluno, 7,1\%, não classificou o que sabe, $1^{\circ}$ Eletrotécnica); considerar o Taylorismo "lento e artesanal", enquanto o Fordismo produz em massa (um aluno, 7,1\%, "pouco", $1^{\circ}$ Eletrotécnica); definir o Fordismo como "quantidade" e o Taylorismo como "sofisticação", numa clara confusão com o Toyotismo (um aluno, 7,1\%, "pouco", $1^{\circ}$ Eletrotécnica); ou Fordismo como produção em série de uma peça, e o Taylorismo como o planejamento do Fordismo (um aluno, 7,1\%, “pouco", $1^{\circ}$ Eletrotécnica).

Nos mesmos moldes, questionou-se sobre o Toyotismo.

GRÁFICO 2 - Qual é seu conhecimento sobre o sistema de trabalho industrial do Toyotismo, ou seja, como a indústria passou a funcionar dos anos $1970 \mathrm{em}$ diante?

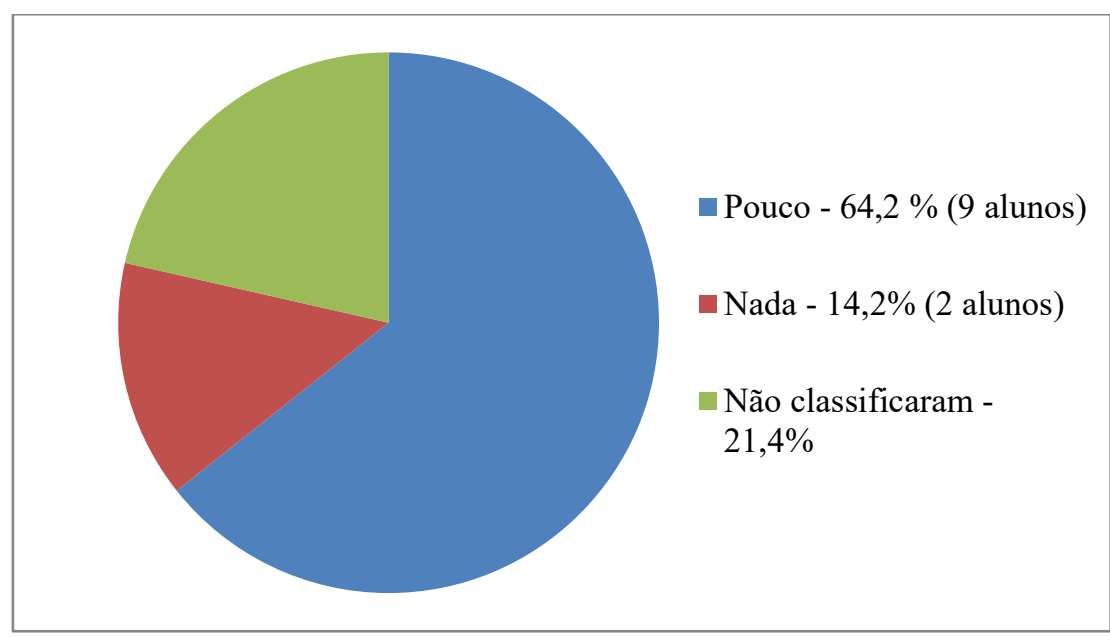

Fonte: Autores.

Daqueles que descreveram seu saber, no Grupo 01 , dois alunos $(14,2 \%$, um classificou como "pouco", o outro não classificou, ambos $1^{\circ}$ Eletrotécnica) mencionaram a necessidade de maior qualificação e domínio de todo o processo de trabalho. No Grupo 02, dois alunos $\left(14,2 \%\right.$, nenhum classificou, ambos do $1^{\circ}$ Eletrotécnica) escreveram sobre uma maior sofisticação dos produtos em oposição ao Fordismo, um aluno (7,1\%, "pouco", $1^{\circ}$ Eletrotécnica) destacou a exploração de mão de obra e produção em massa, e outro $(7,1 \%$, 
Mendes, L. F. de O.; Boechat, L. T.; Garzoni, L. de C.

"pouco", $1^{\text {o }}$ Eletrotécnica) mencionou a necessidade de todos os trabalhadores saberem o "mesmo processo" e a mão de obra multifuncional.

O tópico em relação ao qual os alunos se sentiram mais à vontade em discorrer foi a Guerra Fria.

GRÁFICO 3 - O que você sabe sobre a Guerra Fria?

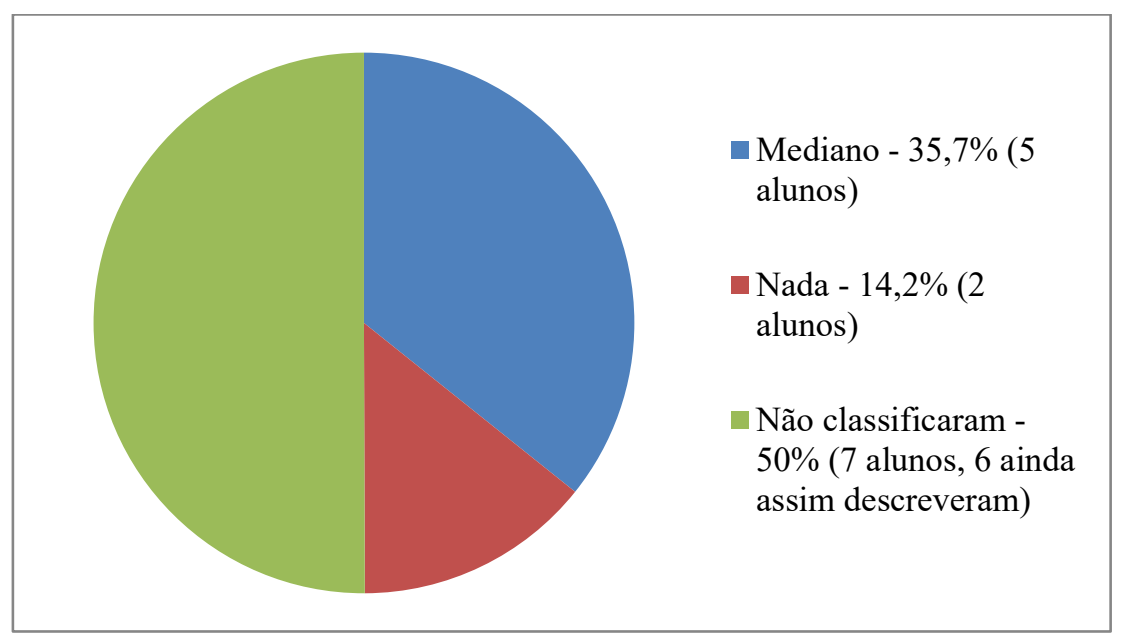

Fonte: Autores.

Dentre os alunos que de alguma forma descreveram seu saber (oito - dois do Grupo 01, ambos do $1^{\circ}$ Eletrotécnica; e seis do Grupo 02, quatro do $1^{\circ}$ Eletrotécnica e dois do $1^{\circ}$ Informática) todos definiram o conflito como uma disputa indireta entre EUA e URSS pela hegemonia mundial, cada potência representando respectivamente Capitalismo e Socialismo. Nos detalhes, quatro alunos (Grupo 02, dois do $1^{\circ}$ Eletrotécnica e dois do $1^{\circ}$ Informática) mencionaram a disputa tecnológica entre as duas potências e/ou corrida espacial, e um aluno (Grupo 02, $1^{\text {o }}$ Informática) destacou o predomínio final do bloco capitalista.

Por outro lado, a pergunta de conhecimentos em que os alunos mais demonstraram dificuldades foi a que questionava sobre as indústrias capitalista e socialista durante os anos 1970-1980.

GRÁFICO 4 - O que você sabe sobre como era o trabalho na indústria do Ocidente (países capitalistas) e na indústria da União Soviética, entre os anos 1970 a 1980? 
Mendes, L. F. de O.; Boechat, L. T.; Garzoni, L. de C.

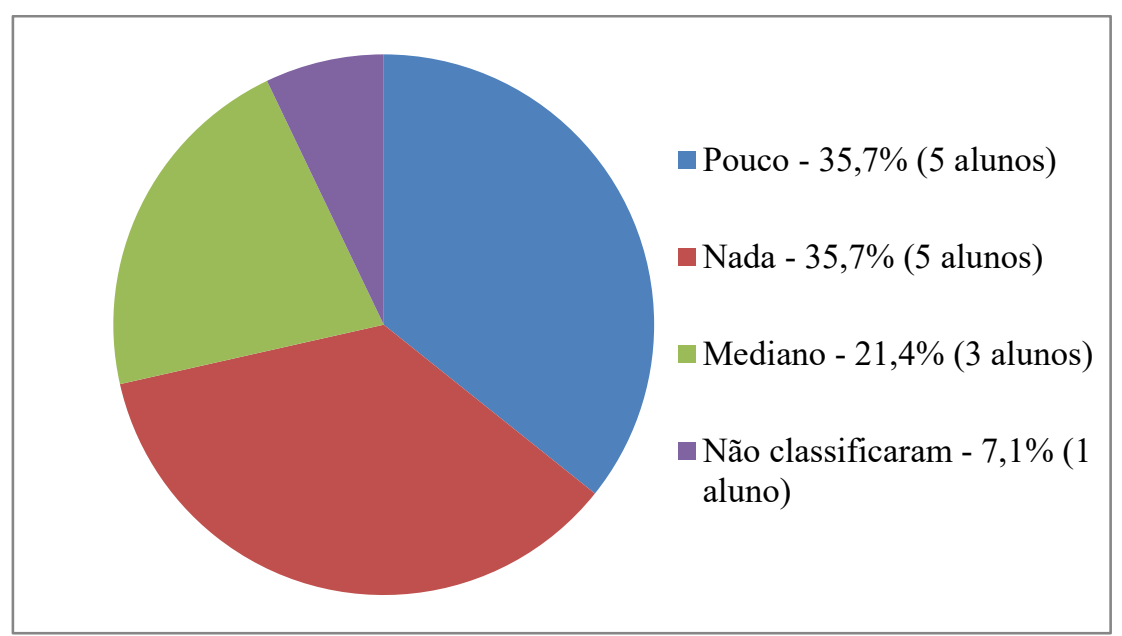

Fonte: Autores.

Nenhum dos participantes explicou sobre o assunto, a não ser um aluno $(7,1 \%)$ do Grupo $01,3^{\circ}$ Informática, que descreveu melhores condições de trabalho no bloco capitalista, o foco de ambos os lados na indústria bélica e a força da URSS na siderurgia.

Quando questionados sobre o desejo de aprender mais sobre esses temas, todos os catorze alunos $(100 \%)$ responderam afirmativamente.

GRÁFICO 5 - Por que você gostaria de saber mais sobre esses temas?

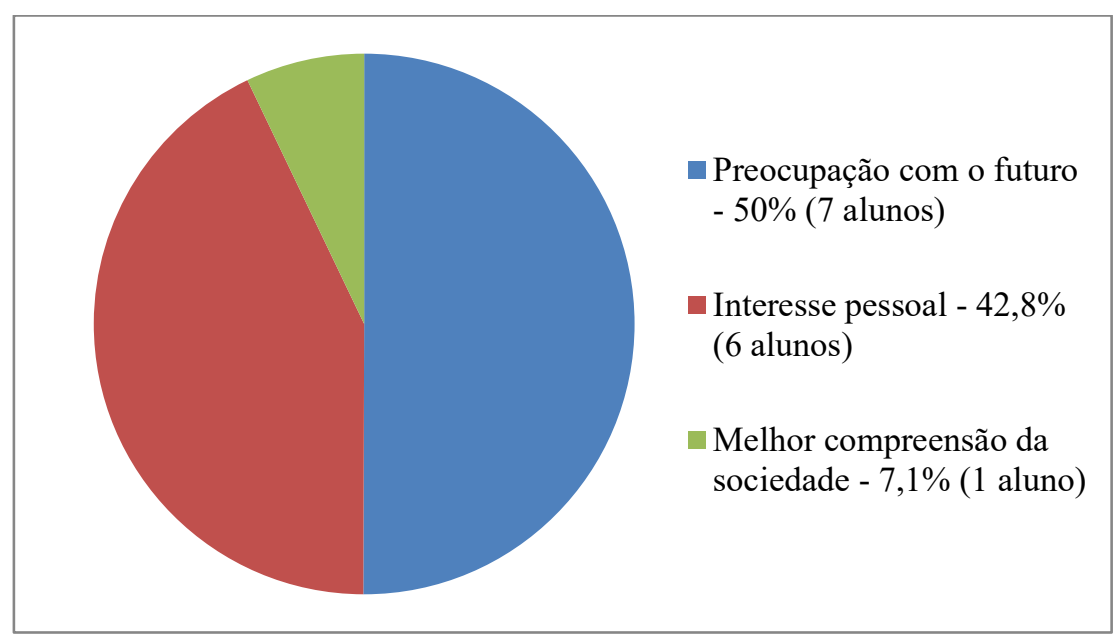

Fonte: Autores.

Sobre perspectivas de trabalho, questionou-se se os alunos preocupavam-se com onde e no que trabalhariam ao término de seus estudos. Treze alunos $(92,8 \%)$ responderam afirmativamente. 
Mendes, L. F. de O.; Boechat, L. T.; Garzoni, L. de C.

GRÁFICO 6 - Depois de se formar, você se preocupa com: onde e como vai trabalhar? Por quê?

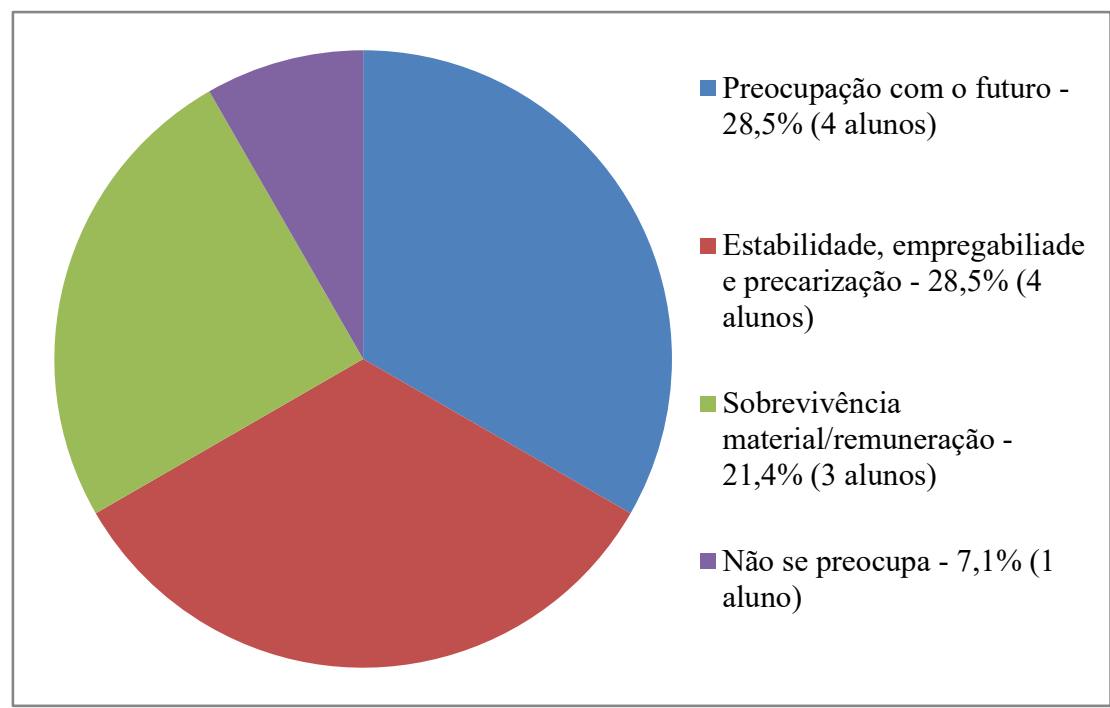

Fonte: Autores.

Ainda nessa temática, foi indagado aos alunos se já pensaram sobre o impacto de seu futuro trabalho na sociedade, e a intensidade deste. Oito alunos $(57,1 \%)$ alegaram nunca terem pensado nisso até o momento do questionário. Notamos também que dois alunos $(14,2 \%)$, um por grupo, afirmaram nunca terem pensado na questão por pensarem primeiro em si.

GRÁFICO 7 - Você já parou para pensar em como seu futuro trabalho pode causar impacto na sociedade? Considera uma influência grande ou pequena?

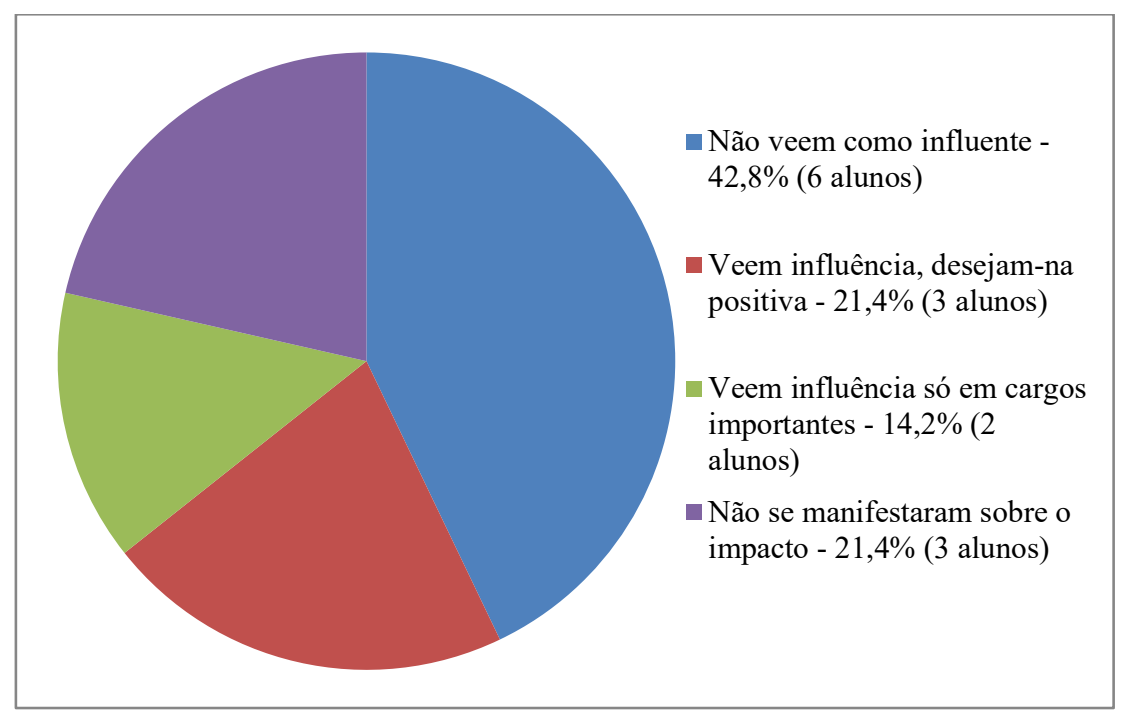

Fonte: Autores. 
Mendes, L. F. de O.; Boechat, L. T.; Garzoni, L. de C.

Considerando as exposições extras feitas pelos alunos em ambas as questões anteriores, um dado importante transparecido nos dados foi a já definida escolha de carreira de cinco alunos (35,7\%): medicina veterinária, engenharia aeronáutica, relações internacionais, arquitetura/química (ainda em indecisão) e carreira docente (professor). Isso revela uma prioridade dos estudantes ao vestibular e ao seguimento dos estudos em áreas distintas das técnicas cursadas no Ensino Médio Integrado (Eletrotécnica e Informática). Destes alunos, três são dos primeiros anos (dois de Eletrotécnica, um de Informática) e um é concluinte ( $3^{\circ}$ Informática).

Sobre posicionamento político, obteve-se os seguintes dados:

GRÁFICO 8 - Você tem algum posicionamento político? O que o(a) levou a construir essa visão de mundo

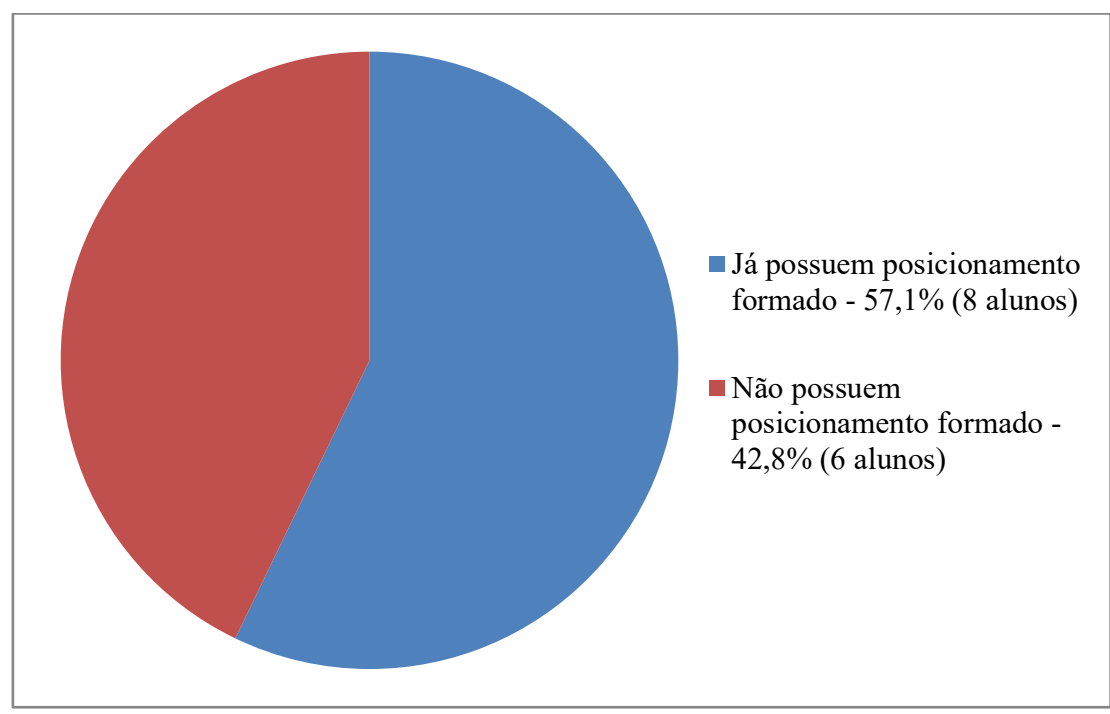

Fonte: Autores.

Os três alunos $(21,4 \%)$ que desejaram expor seu posicionamento descreveram-se de esquerda, tendo como justificativa a inclusão social das minorias e explorados. Convém mencionar que um dos alunos $(7,1 \%)$ que alegou não ter um posicionamento definido afirmou-se, ainda assim, favorável aos direitos humanos. Já outro $(7,1 \%)$ que negou ter um posicionamento formado alegou já ter tido um no passado, porém repensou-o e agora busca melhor embasamento até definir um novo. Sobre influências na formação de seu posicionamento, três alunos $(21,4 \%)$ mencionaram obras de referência (livros ou filmes), dois alunos $(14,2 \%)$ a escola, e um aluno $(7,1 \%)$ sua família.

Por fim, perguntou-se quais relações os alunos percebem entre as disciplinas de Ciências Humanas e a área técnica de seus cursos, ou se elas sequer existem. 
Mendes, L. F. de O.; Boechat, L. T.; Garzoni, L. de C.

GRÁFICO 9 - Você considera que as matérias de Humanas (História, Geografia, Filosofia, Sociologia) são bem articuladas com a área técnica do seu curso? Por que, e qual sua opinião sobre isso?

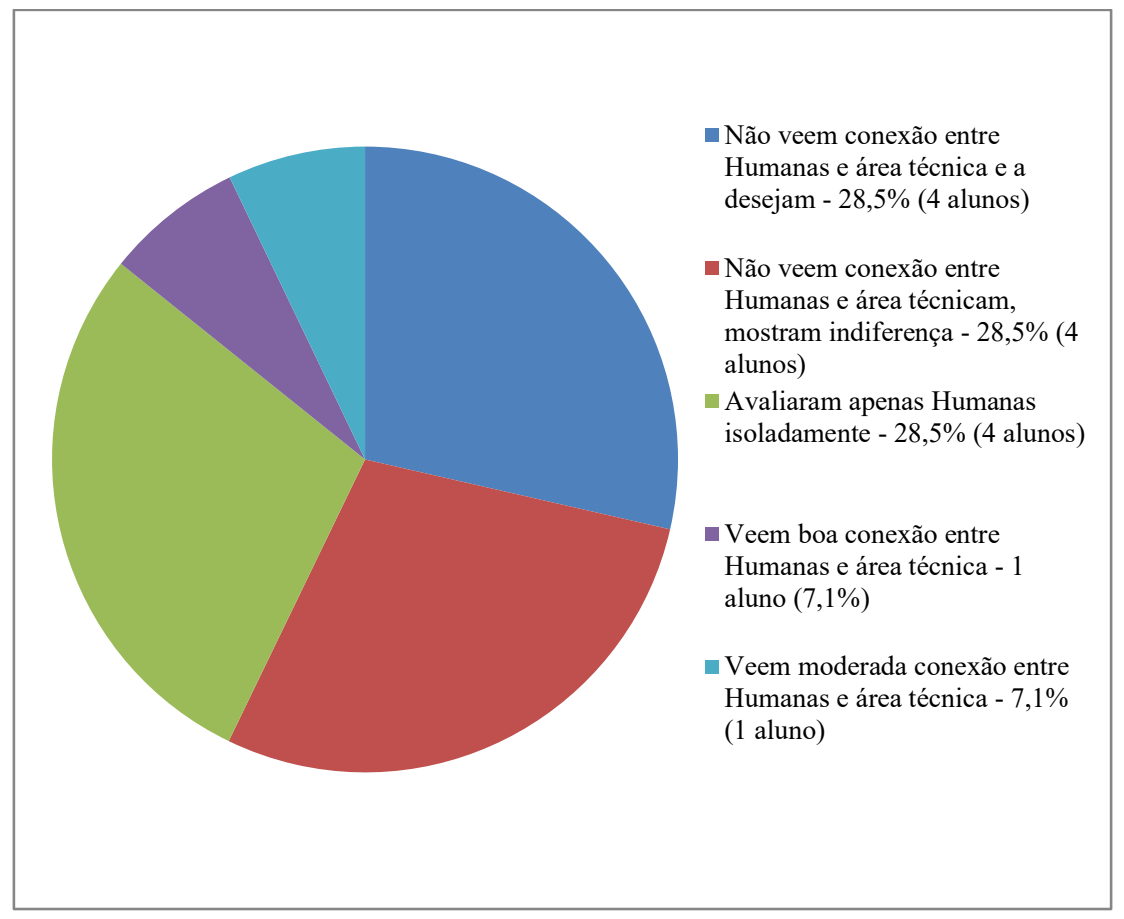

Fonte: Autores.

Quatro alunos (28,5\%) não compreenderam a questão e, sem relacionarem as duas áreas entre si, responderam avaliando somente as disciplinas de Humanas. No entanto, um desses alunos $(7,1 \%)$, concluinte do $3^{\circ}$ Informática (Grupo 01) estruturou comentário razoavelmente detalhado sobre não ter sentido aprender o suficiente dessas disciplinas ao longo do Ensino Médio Integrado, alegando como motivo as metodologias de ensino adotadas. Outros quatro alunos $(28,5 \%)$ mostraram-se incomodados com o quadro de não conexão entre as duas áreas, chegando a afirmar que falta contexto às disciplinas técnicas não bastando só fazer os cálculos, mas entender o "contexto" dos cálculos (dois alunos), a área técnica "atrapalha" o desenvolvimento das disciplinas de Humanas, gerando desinteresse pelo curso (um aluno), ou que essa distância é parte de uma má articulação das Humanas ao ensino brasileiro no geral (um aluno)

Porém, é notável que, mesmo admitindo a questão do distanciamento, os outros quatro alunos vejam-na com aparente indiferença. Nas respostas, apenas limitaram-se a dizer que isso ocorre por seus cursos serem "de Exatas" (três alunos), um deles chegando a detalhar não ser um problema que o incomode e que disciplinas como História lhe servem mais como “passatempo". O estudante em questão (Grupo $01-1^{\circ}$ Eletrotécnica) é um ingressante vindo do Ensino Fundamental, o que revela como a separação das disciplinas em áreas já é marcada 
Mendes, L. F. de O.; Boechat, L. T.; Garzoni, L. de C.

muito profundamente nos alunos ao concluírem essa etapa de formação; e como o Ensino Médio Integrado, se não realmente articulado, falha em superar tal visão no desenvolvimento da EPT. Por fim, os dois estudantes restantes ou afirmaram que as disciplinas de Humanas são, sim, bem articuladas à área técnica, ajudando no conhecimento político e formação de opinião (um aluno, 7,1\%), ou apenas moderadamente articuladas, sem maior desenvolvimento da razão (um aluno, 7,1\%).

\section{Elaborando o produto educacional: RPG trabalho nos extremos}

De acordo com as informações obtidas pelos questionários e as problemáticas levantadas, foi elaborado um produto educacional na forma de um sistema de RPG com base nas regras do modelo D207 - adaptado, mais precisamente, da versão 3.5 do sistema Dungeons \& Dragons (D\&D). A proposta é que o jogo possa ser utilizado junto ao Ensino Médio Integrado e o professor assuma a posição de mestre (exercida, na elaboração deste trabalho, pelo pesquisador) conduzindo sessões do RPG com seus alunos para desenvolver temas que liguem as Ciências Humanas à EPT.

O sistema, denominado "Trabalho nos Extremos" $"$ ", busca proporcionar aos alunos a oportunidade de interpretar operários estadunidenses ou soviéticos durante a Guerra Fria. O enredo fictício da narrativa (denominada, em RPGs, "aventura") situa-se na imaginária nação caribenha de San José Obrero, devastada pelo conflito entre uma ditadura militar pró-EUA e uma guerrilha socialista pró-URSS. Em 1978, EUA e URSS, como tentativa final de salvar a "détente" (“distensão" - suavização das tensões da Guerra Fria durante os anos 1970) surpreendem o mundo mediando um cessar-fogo entre as duas facções e anunciando um projeto aeroespacial conjunto no solo da ilha, cujos frutos serão partilhados pelas duas potências. Cada uma recruta trabalhadores voluntários que queiram mudar-se a San José Obrero, em troca de vantagens de carreira e uma boa remuneração, para auxiliar com seus conhecimentos na concretização do projeto. Aí entram os personagens dos jogadores.

A proposta central de "Trabalho nos Extremos" não é opor os operários estadunidenses e soviéticos, e sim, no contexto estabelecido, fazer com que trabalhem em

\footnotetext{
${ }^{7}$ Sistema de RPG popularizado pela marca "Dungeons \& Dragons", utiliza por base um dado de 20 faces. Possui licença aberta, o que permite a pesquisadores desenvolverem jogos com seu sistema de regras sem o pagamento de direitos autorais.

${ }^{8}$ Uma referência e homenagem ao livro "Era dos Extremos", do historiador Eric Hobsbawn, referente ao séc. XX. 
Mendes, L. F. de O.; Boechat, L. T.; Garzoni, L. de C.

cooperação. Além disso, os personagens utilizam o mesmo alojamento, estão sujeitos a compartilharem outros ambientes do cenário de jogo (como uma sala de descanso, ou o refeitório) e possuem tanto histórias de vida quanto dilemas pessoais que os humanizam e ressaltam características em comum. É nesse aspecto do produto educacional que se desdobra o componente político da presente pesquisa, relacionado não só à EPT, mas ao presente cenário mundial: estimular a troca de ideias e o agir conjunto de pessoas com posicionamentos opostos, usando como cenário justamente a Guerra Fria - auge dessa tendência à polarização. Interpretando seus personagens e lidando com os empecilhos que a “ordem bipolar" impõe ao mundo do jogo, os alunos precisarão vencer preconceitos sobre a potência e sistema adversários e, colaborando entre si, avançar no enredo. Em suma, “ouvir o outro" não apenas no tocante ao jogador distinto à mesa, mas a um personagem pertencente a um bloco rival, através do potencial comunicativo e de interpretação que um RPG oferece.

As noções tecnológicas e organizacionais sobre o mundo do trabalho - ou "fundamentos científicos que sustentam a produção" (SAVIANI, 2007) - são desenvolvidos em "Trabalho nos Extremos" na forma das "classes" de personagens, aqui chamadas de "sistemas de trabalho". Ao invés do "guerreiro", "mago" ou "paladino", que em sistemas como D\&D delimitam ou reforçam determinadas habilidades de cada personagem, neste RPG há quatro sistemas de trabalho disponíveis à escolha dos alunos: Fordismo, Toyotismo, Taylorismo Soviético e Stakhanovismo ${ }^{9}$. Os dois primeiros, mais comumente trabalhados no currículo do Ensino Médio, expõem ao aluno as mudanças no trabalho ocorridas no Capitalismo ao longo do séc. XX, mais notadamente a partir de fins dos anos 1970, que levaram à atual flexibilização do capital e emprego (ALVES, 1999; ANTUNES, 1999, 2017). Os dois últimos preenchem a lacuna, demonstrada nos questionários, sobre o total desconhecimento dos alunos sobre o desenvolvimento da indústria soviética, inclusive seus percalços e permanências em relação ao sistema capitalista (através do próprio Taylorismo advogado por Lênin) e as mais marcantes diferenças em relação às suas contrapartes ocidentais (FILTZER, 1996; ARBIX, 1997; AUGUSTIN, 2015; LAZAGNA, 2017).

\footnotetext{
${ }^{9}$ Conceito trabalhado a partir de Augustin (2015), trata-se de uma "variação" do Taylorismo na URSS, com auge no período stalinista, em que, a partir dos esforços do minerador de carvão Alexei Stakhanov (1906-1977), o governo socialista passou a propagandear os feitos heroicos de determinados operários para que servissem de modelo aos demais, fazendo-os competir por quem produziria mais à coletividade pelo conceito denominado "emulação socialista". Além de disponibilizar outro sistema de trabalho aos personagens soviéticos (igualando os dois ocidentais), a inclusão do Stakhanovismo no jogo buscou trabalhar conceitos como propaganda e as relações entre trabalho, Estado e ideologia. 
As características de cada sistema de trabalho relacionam-se às circunstâncias que os fundamentam, visando que o aluno possa identificá-las, e compará-las, conforme interpreta seu personagem. O Fordista, por exemplo, começa o jogo com menos perícias (conhecimentos específicos que determinam se o personagem é capaz ou não de realizar determinada tarefa no jogo), porém as possui em níveis maiores de proficiência (contabilizados de 1 a 5 - no caso, começando Nível 3). Ou seja, o trabalhador fordista é mais especializado, dominando menos tarefas de produção; porém possui maior conhecimento das tarefas que domina, devido à repetição e função fixa à linha de montagem. O Toyotista, por sua vez, começa com mais perícias que o Fordista, mas todas Nível 1. Isso reflete a condição desse operário quanto ao seu perfil multitarefa, não possuindo só uma função à linha de montagem, mas sendo menos especializado nas tarefas que realiza - o que explica seus níveis menores de proficiência. Todos os quatro sistemas de trabalho seguem essa dinâmica, suas potencialidades e limitações baseadas em seu funcionamento na indústria, assim como a própria história de vida dos personagens. Um operário fordista tende a ser mais velho, vindo de uma carreira mais estável e com maiores ganhos. O stakhanovista convive com a fama por algum feito profissional que realizou na União Soviética e foi propagandeado pelo governo - dentre outros contextos.

Além de escolher um sistema de trabalho, o aluno optará por uma especialização. Essa é sua área específica de atividade, e cada uma habilita perícias exclusivas que um trabalhador de outra especialização não pode utilizar. Para o uso inicial do RPG, foram elaboradas as especializações de Eletrotécnica e Informática, visando os cursos Integrados da instituição na qual foi aplicado.

Além das perícias necessárias para a realização de ações especializadas, o jogo é regido por quatro habilidades comuns a todos os jogadores: Força, Reflexos, Inteligência e Sociabilidade - variando apenas os valores numéricos que os personagens possuem em cada uma. Seja usando perícias ou habilidades, o resultado das ações dos jogadores é definido por jogadas de dados ${ }^{10}$, seus resultados somados aos valores pré-estabelecidos desses parâmetros presentes na ficha de personagem, que deve igualar ou superar um valor de dificuldade

\footnotetext{
${ }^{10}$ Como o D\&D 3.5 utiliza o sistema D20 de regras, 6 tipos de dados diferentes são incluídos no RPG Trabalho nos Extremos: d20 (mais usado, com 20 faces), d12 (12 faces), d10 (10 faces), d8 (8 faces), d6 (mais tradicional e encontrado em vários jogos de tabuleiro, 6 faces) e d4 (4 faces). Esses dados podem ser adquiridos em lojas especializadas em RPG, sejam elas físicas ou pela Internet. $\mathrm{Na}$ indisponibilidade ao professor, aplicativos gratuitos para celular, como o RPG Simple Dice (Android), simulam as jogadas de dados digitalmente, até mesmo já somando bônus pré-definidos das fichas de personagens. 
Mendes, L. F. de O.; Boechat, L. T.; Garzoni, L. de C.

estabelecido pelo mestre para ocasionar o sucesso da ação. Para a utilização das perícias, os personagens devem usar ferramentas (EX: alicate, furadeira, chave de fenda, chave inglesa) e itens (EX: fita isolante, cabos elétricos, disquetes, parafusos), sendo que o personagem de cada sistema de trabalho começa com uma quantidade pré-determinada destes e, em sua falta, deverão ser encontrados pelo cenário. Esses artefatos foram adicionados ao jogo emulando os reais empregados tanto por técnicos de Eletrotécnica quanto Informática, assim como suas regras de utilização.

$\mathrm{Na}$ ficha de personagem (FIGURA 01) também constam informações sobre pontos de vida (definindo o máximo de dano que o personagem pode sofrer sem morrer), traje (que influencia seu deslocamento, assim como quantas ferramentas e itens ele pode carregar), dinheiro disponível e pontos de experiência, adquiridos através da superação dos desafios da aventura para que o personagem suba de nível (de 1 até 10) e possa evoluir a proficiência de suas perícias ou adquirir novas, aumentar valores de habilidades e pontos de vida, dentre outras melhorias definidas, também, pelo sistema de trabalho adotado.

Durante o RPG, os jogadores encontram outros personagens, não controlados por eles, com quem podem interagir: aliados, inimigos ou apenas neutros em relação às suas ações. Estes são denominados Personagens Não-Jogáveis, ou $\mathrm{PNJS}^{11}$, interpretados pelo mestre (incluindo diálogos) conforme forem encontrados pelos jogadores, também possuindo fichas de jogo no mesmo formato que as dos personagens jogáveis para definir os resultados de suas interações, incluindo as jogadas de dados. No caso do cenário de aventura utilizado, os PNJs incluem outros operários, guardas, cientistas e corpo administrativo do "Centro de Pesquisas Aeroespaciais", tanto estadunidenses quanto soviéticos. É papel do mestre, também, descrever os locais inclusos nos mapas da aventura conforme acessados pelos jogadores, e realizar narrações visuais das ações e situações em que os personagens se envolvem, seguindo as instruções do material de jogo.

${ }^{11}$ Do original, em inglês, Non-Playing Characters - NPCs. 
Mendes, L. F. de O.; Boechat, L. T.; Garzoni, L. de C.

FIGURA 01 - Ficha de jogo do RPG Trabalho nos Extremos.

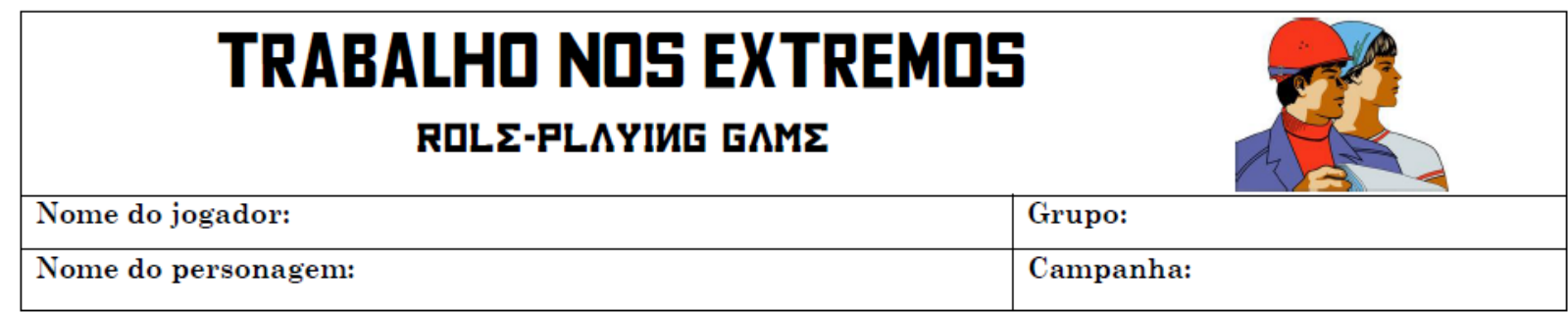

Dados do personagem:

\begin{tabular}{|l|l|}
\hline Gênero: & Altura / Peso: \\
\hline Idade: & Cabelos: \\
\hline Pele: & Olhos: \\
\hline Nacionalidade: & \\
\hline
\end{tabular}

\begin{tabular}{|l|}
\hline Nível de personagem: \\
\hline Dado de Evolução: \\
\hline Pontos de Vida (PV): \\
\hline
\end{tabular}

Habilidades:

\begin{tabular}{|l|l|l|l|}
\hline $\begin{array}{l}\text { Força: } \\
\text { (Escalar, Nadar, Puxar, Empurrar, } \\
\text { Carregar...) }\end{array}$ & $\begin{array}{l}\text { Reflexos: } \\
\text { (Ver, Ouvir, Correr, Saltar, } \\
\text { Desviar...) }\end{array}$ & \\
\hline $\begin{array}{l}\text { Inteligência: } \\
\begin{array}{l}\text { (Decifrar, Planejar, Consertar, } \\
\text { Analisar, Interpretar...) }\end{array}\end{array}$ & $\begin{array}{l}\text { Sociabilidade: } \\
\text { (Convencer, Disfarçar, Intimidar, } \\
\text { Cativar, Negociar...) }\end{array}$ & \\
\hline
\end{tabular}
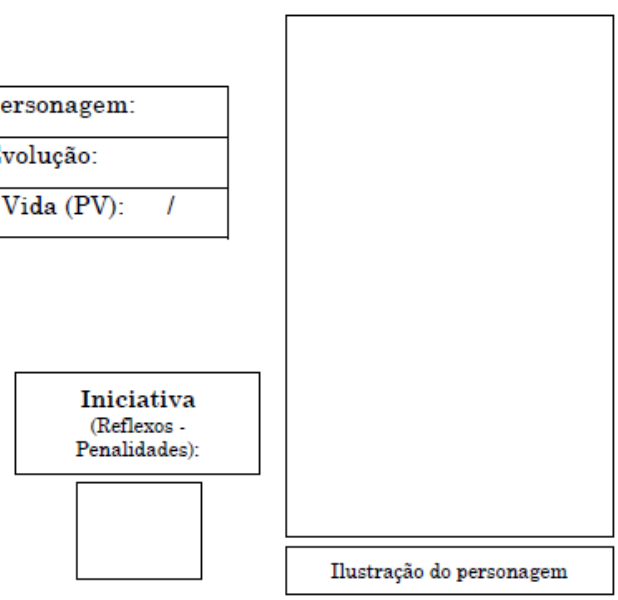

Sistema de Trabalho:

Especialização:

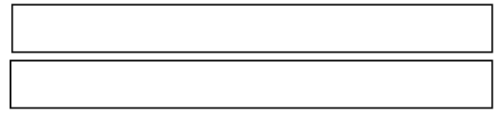

Experiência (XP):

Perícias:

\begin{tabular}{|l|l|l|l|}
\hline & Nível: & & Nível: \\
\hline & Nível: & & Nível: \\
\hline & Nível: & & Nível: \\
\hline & Nível: & & Nível: \\
\hline & Nível: & & Nível: \\
\hline
\end{tabular}

Ferramentas:

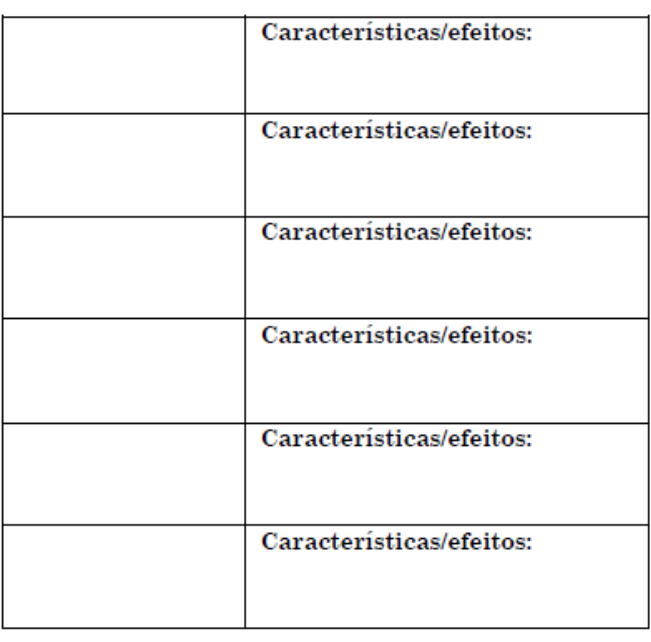

Itens:

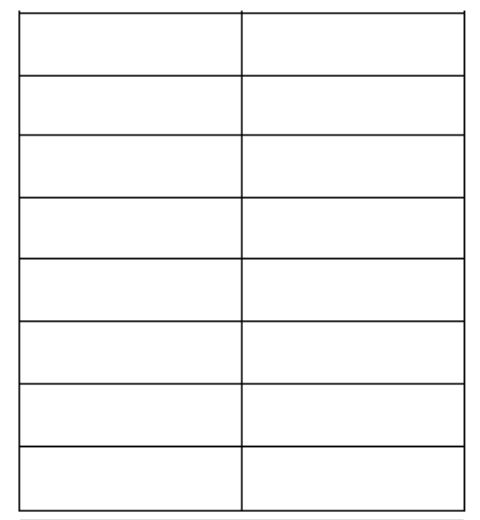

Dinheiro:
Traje:

\begin{tabular}{|l|}
\hline Nome: \\
\hline $\begin{array}{l}\text { Penalidade/ } \\
\text { Deslocamento: }\end{array}$ \\
\hline $\begin{array}{l}\text { Espaço máximo: } \\
\text { Itens: } \\
\text { Ferramentas: }\end{array}$ \\
\hline $\begin{array}{l}\text { Proteção contra } \\
\text { Dano (PD): } \\
\text { Reflexos + Traje }\end{array}$ \\
\hline Habilidades especiais: \\
\\
\end{tabular}

Fonte: Autores. 
Na preparação do RPG, os jogadores podem escolher dentre doze personagens de fichas e históricos já prontos (sendo seis estadunidenses e seis soviéticos), ou criar seus próprios personagens seguindo as regras existentes. Parte dos personagens pré-estabelecidos não escolhidos tende a ser incorporada à aventura como PNJs controlados pelo mestre. Como jogo cooperativo, um RPG não tem "ganhadores" ou "perdedores", o objetivo sendo atingir o desfecho da história narrada - que é, inclusive, aberto, podendo ser modificado de inúmeras maneiras pelas decisões dos jogadores e como o cenário reage a elas (através do mestre).

O desenvolvimento do enredo do RPG Trabalho nos Extremos direciona-se justamente a um questionamento sobre os fins do trabalho e seu impacto social, questões abordadas com os alunos no questionário prévio: através da coleta de pistas e revelações numa trama regada a toques de espionagem (inclusive com PNJs da $\mathrm{CIA}^{12}$ e $\mathrm{KGB}^{13}$, e a possibilidade de estes recrutarem os personagens dos jogadores), os alunos descobrirão que o Centro de Pesquisas Aeroespaciais na verdade esconde um projeto de armas de destruição em massa. Tanto EUA quanto URSS cooperam nessa iniciativa, visando dividir os resultados - os sistemas e componentes desenvolvidos pelos operários dos jogadores, na verdade, destinados a isso. Surge a escolha quanto a continuarem colaborando com seus respectivos países (ou até mesmo sabotar o "lado inimigo", evitando que ele compartilhe dos resultados), sabotar o projeto em nome da paz mundial, ou simplesmente abandonar a base para evitar maior envolvimento. Devido a possíveis complicações da trama, uma ogiva nuclear em construção na ilha pode ser inclusive ativada, e tanto os conhecimentos de Eletrotécnica quanto os de Informática são necessários ao seu desarme.

Surge, assim, um contexto de múltiplos finais ao jogo: o incidente pode permanecer encoberto, mantendo a Guerra Fria como de fato se desenrolou anos 1980 adentro; ou os jogadores podem expor a verdade sobre o projeto das potências (com a explosão da bomba ou não), provocando repercussões internacionais de variada magnitude.

Além da problemática quanto à apropriação do trabalho, as situações surgidas ao longo do jogo, compondo a rotina dos personagens no Centro de Pesquisas Aeroespaciais conforme descobrem indícios da conspiração, busca estimular reflexões sobre problemáticas dessa apropriação que os alunos tendem a encontrar em sua vida profissional. Todos os jogadores são instruídos, por exemplo, a organizar uma jornada de trabalho de oito horas diárias na base dentro de um total de dez horas disponíveis, estipulando se desejam incluir as horas vagas no

\footnotetext{
${ }^{12}$ Sigla de Central Intelligence Agency (Agência de Inteligência Central), principal órgão de Inteligência dos EUA.

${ }^{13}$ Sigla de Komitet Gosudarstvennoy Bezopasnosti (Comitê para Segurança do Estado), principal órgão de Inteligência da antiga URSS. 
início, término ou meio do expediente. Pouco a pouco, as rígidas regras do local são reveladas aos jogadores, como o nível de segredo do projeto impedir que deixem a base sem autorização (somente aos domingos, avisando com antecedência e apenas para passeios pré-definidos), obrigando-os a cumprir um toque de recolher e definindo diversas áreas do cenário como proibidas. Câmeras e guardas armados são encontrados em quase todos os lugares, e supervisores (nacionalidades alternando-se entre estadunidense e soviética) vigiam a produtividade dos operários para intervirem caso achem-na baixa. Em dado ponto da narrativa, os jogadores descobrirão inclusive existir uma prisão na base para encarcerar trabalhadores que desobedeçam às regras.

Em suma, a denominação "Nos Extremos" atribuída ao trabalho como é problematizado no RPG não se refere apenas ao contexto da Guerra Fria, mas às condições impositivas e limitadoras em que se dará ao ser realizado pelos personagens no Centro de Pesquisas Aeroespaciais. Buscou-se, por essa abordagem, desnudar as contradições do mundo do trabalho existentes na realidade, estimulando a reflexão dos alunos sobre sua formação e como nele se inserirão.

O produto educacional consistindo no RPG é constituído de um Livro Básico (com contextualização da Guerra Fria e sistemas de trabalho industrial, e todas as regras gerais de jogo, incluindo simulações para melhor exemplificação) e um suplemento denominado Projeto San José, descrevendo os pormenores da aventura inicial criada ao jogo (com informações sobre o país fictício em que é situada, as fichas prontas dos doze personagens pré-estabelecidos e dos PNJs, a descrição passo-a-passo dos acontecimentos da aventura para guiar o mestre, mapas, dentre outros detalhes). A Ficha de Jogo foi inclusa no Livro Básico, mas também consta em separado para facilitar sua impressão.

Ao término das aplicações, os alunos envolvidos responderam a um questionário semiestruturado pós-jogo sobre sua experiência com o RPG e reflexões proporcionadas, inclusive em comparação aos temas previamente indagados no questionário inicial.

\section{APLICAÇÃO DO RPG, RESULTADOS E DISCUSSÕES}

As sessões de RPG foram realizadas nas dependências do IFSULDEMINAS Campus Poços de Caldas em oito encontros, sendo quatro por grupo, entre os meses de outubro e dezembro de 2019. Foram realizadas, através de agendamento prévio com os alunos, às quartas e sextas-feiras, aproximadamente das $13 \mathrm{~h}$ às $17 \mathrm{~h}$, horários em que tanto os estudantes dos primeiros quanto do terceiro anos dos cursos não possuíam aulas ou outras 
atividades programadas. Deste modo, cada grupo jogou cerca de 16 horas de RPG, incluindo nessa quantia o tempo dedicado à criação dos personagens na primeira sessão.

O material do RPG (Livro Básico, suplemento Projeto San José e Ficha de Jogo) foi todo disponibilizado previamente em arquivos PDF aos jogadores para referência. Estes os gravaram em seus celulares e os consultaram constantemente ao longo das sessões - tornando desnecessária, com exceção das fichas, sua impressão.

Houve casos pontuais de faltas de alunos a algumas das sessões (avisadas previamente, o que permitiu ao pesquisador se preparar para desenvolver o enredo considerando a ausência do personagem) e alunos que chegaram atrasados ou saíram antes do horário de término. Porém, observou-se no geral pontualidade e comprometimento dos jogadores que permaneceram até a última sessão de cada grupo.

Dos catorze alunos participantes, treze criaram personagens originais ao jogo, com exceção de apenas um estudante do Grupo 01 ( $3^{\circ}$ Informática) que utilizou uma ficha préestabelecida, modificando somente o nome do personagem. Onze optaram por personagens com a mesma especialização de seus cursos. Apenas três alunos de Informática criaram personagens com a outra especialização, ou seja, Eletrotécnica.

No Grupo 01, foram estabelecidos quatro personagens soviéticos e três personagens estadunidenses. Notou-se nesse grupo uma montagem de fichas ocorrida de forma extremamente rápida (aprox. 30 minutos), pelo fato de os quatro alunos do $3^{\circ}$ Informática já terem trazido suas fichas praticamente prontas à sessão, tendo-as elaborado ao consultarem o Livro Básico. Este grupo, idealizado justamente para analisar a aplicação da ZDP vygotskyana, contou com a inesperada revelação de que dois dos referidos alunos do $3^{\circ}$ Informática já tinham experiência com jogos de RPG (justamente D\&D, sistema em que o produto educacional foi baseado), um deles trazendo inclusive um conjunto próprio de dados à sessão. Isso não apenas colaborou a um início rápido, em que tais alunos orientaram os três do $1^{\mathrm{o}}$ Eletrotécnica, acelerando a montagem de suas fichas, mas também garantiu um entendimento e inserção mais rápidos desses estudantes no RPG em si, com considerável avanço do enredo já na $1^{\text {a }}$ sessão e a interpretação dos personagens dos alunos do $3^{\text {o }}$ Informática, dotada de maior desenvoltura, servindo de referência aos iniciantes.

Essa observação contribui à corroboração do potencial do jogo à luz da sóciointeração; e torna-se ainda mais relevante ao considerarmos que o Grupo 02, formado apenas por alunos dos primeiros anos e iniciantes em RPG, demorou algo próximo de metade da $1^{\mathrm{a}}$ sessão (entre $1 \mathrm{~h}$ e $2 \mathrm{~h}$ ) somente para montar suas fichas, entre constantes dúvidas e longos debates. Cabe comparar, também, como o Grupo 02 avançou pouco no enredo do jogo no tempo restante da 
$1^{\text {a }}$ sessão, até mesmo levando em conta a menor duração ainda disponível, devido a maiores dificuldades em assimilar as regras de jogo e a ações que "voltavam", anuladas após alguma narração, devido a enganos dos alunos ao consultarem as fichas.

Considerando a proposta do RPG em incentivar o diálogo entre opostos políticos, ambos os grupos demonstraram dificuldades na cooperação entre personagens estadunidenses e soviéticos - mesmo com as oportunidades existentes no enredo para tal. Jogadores controlando operários de uma mesma nacionalidade demonstraram tendência em se fechar em um grupo comum, suas ações visando sabotar ou expor o grupo "rival”. A dinâmica como isso ocorreu revelou-se invertida em cada mesa de jogo: no Grupo 01, os jogadores começaram mais dispersos e até colaborando entre diferentes nacionalidades (duas primeiras sessões), para então se polarizarem e o final de enredo ser fortemente marcado pela oposição entre estadunidenses e soviéticos (duas últimas sessões). Já no Grupo 02, a polarização mostrou-se mais intensa de início (duas primeiras sessões), para então, embora ainda presente, ser um tanto diluída e menos influente sobre o desfecho (duas últimas sessões).

Em ambos os grupos, conhecimentos prévios sobre a Guerra Fria influenciaram marcadamente as interpretações e decisões dos jogadores - e, embora as interações presentes no jogo propusessem algo mais abrangente, parte dessas ideias persistiu nos jogadores até o final, contribuindo à polarização de personagens. No Grupo 01 , um aluno do $3^{\circ}$ Informática interpretou um personagem soviético altamente calcado em estereótipos sobre o país e seu regime: lutador de boxe ${ }^{14}$, tinha, segundo descrição do jogador, o Manifesto Comunista tatuado ao longo das pernas. Conforme transcorreram as sessões, o aspecto caricatural do personagem tornou-se cada vez mais evidente - até que, entre a terceira e quarta sessões, sua influência sobre os demais operários soviéticos levou-os a querer se apoderar da ogiva nuclear construída na base somente ao seu país. Isso conduziu a um final belicoso e violento que causou a morte do próprio personagem estereotipado e alguns PNJs, devido ao confronto com o outro grupo de jogadores (estadunidenses) que decidira sabotar o projeto. Nas palavras do aluno, após o término da última sessão, ele apenas fora condizente com sua proposta de interpretar um "russo louco". Aqui vemos que o apego a estereótipos, sejam eles sobre a Guerra Fria ou o mundo do trabalho, pode comprometer o potencial do jogo devido ao direcionamento pela interpretação de personagem.

No Grupo 02, os alunos demonstraram, desde a primeira sessão, a influência de seus conhecimentos sobre Guerra Fria ou tópicos relacionados. Lembrando que, nesta mesa de

\footnotetext{
14 Ivan Drago, personagem do ator Dolph Lundgren no filme "Rocky IV", de 1985, constituindo evidente influência. 
jogo, todos os participantes eram dos primeiros anos, revelando como tal aprendizado foi trazido de sua trajetória no $9^{\circ}$ ano do Ensino Fundamental II. Num "brainstorming 15 " durante a criação de personagens, houve, dentre diversas outras referências, menções à Crise dos Mísseis em Cuba (1962), Anastacia Romanov e Olga Benário (enquanto alunos debatiam um nome a uma personagem russa), o incidente nuclear de Chernobyl (1986), e o fim da Guerra Fria e URSS. Enquanto um aluno jogando com um personagem estadunidense zombava os colegas do bloco oposto quanto a "querer vê-los falir em 1989", os alunos de personagens soviéticos brincaram entre si reproduzindo "memes ${ }^{16 "}$ de Internet como os termos "nós" ou "nosso" se referirem a contextos socialistas. No desenrolar das sessões, a rivalidade entre grupos de operários encaminhou a história a um impasse similar ao do Grupo 01: personagens soviéticos querendo garantir a posse da arma nuclear somente aos seus compatriotas, e estadunidenses engajados em sabotá-la. O diferencial foi um aluno de personagem soviético ( $1^{\circ}$ Informática) que, com ações alternando-se entre os dois blocos (segundo observado pelo pesquisador, devido a dificuldades em definir uma linha interpretativa única, demonstrando ao invés disso posturas reativas - e contraditórias - a cada acontecimento), terminou por ajudar o grupo contrário ao projeto no final, inclusive sacrificando-se. Partiu desse mesmo jogador a ideia de, descoberta a verdade sobre as armas desenvolvidas na base, revelá-la com provas a todos os trabalhadores, o que ocasionou uma revolta geral pela qual os operários tomaram as instalações e expuseram seu real propósito ao mundo, gerando repercussões internacionais muito maiores que o desfecho do Grupo 01 (no qual a Guerra Fria permaneceu inalterada). No geral, o Grupo 02 produziu um final mais satisfatório a todas as partes envolvidas, além de poupar mais PNJs e recorrer menos a soluções violentas.

Os resultados da experiência, em ambos os grupos, puderam ser analisados a partir das respostas ao questionário pós-jogo. Dos catorze alunos que participaram da pesquisa, onze o entregaram preenchido ${ }^{17}$. Inicialmente, foi requisitado que expusessem, livremente, quais aspectos do RPG mais os agradaram ou causaram envolvimento.

\footnotetext{
15 Significando, em inglês, "tempestade de ideias", refere-se a uma dinâmica em que os participantes sugerem diversas ideias, e debatem as contribuições dos demais, buscando definir um curso de ação ou resolução de problema. No caso desta pesquisa, a montagem das fichas de personagens do RPG.

${ }^{16}$ Imagens, vídeos, "hashtags" ou expressões, geralmente em contexto de humor, que se difundem pela Internet de modo viral.

${ }^{17}$ Em cada um dos grupos, houve a desistência de um estudante: no Grupo 01, um dos jogadores só participou da primeira sessão, por afirmar não poder mais comparecer nos dias de jogo, deixando também de preencher o questionário pós-jogo. No Grupo 02, outro aluno jogou igualmente apenas uma sessão, alegando que sua saída ocorreu por pressões familiares. Este preencheu, porém, o questionário pós-jogo, referente à única sessão da qual REVISTA ENSAIOS E PESQUISA EM EDUCAÇÃO E CULTURA - 2020. 1 / vol . 5 - n.8 
Mendes, L. F. de O.; Boechat, L. T.; Garzoni, L. de C.

GRÁFICO 10 - Comente sobre os aspectos do jogo de RPG que mais o(a) agradaram ou causaram envolvimento.

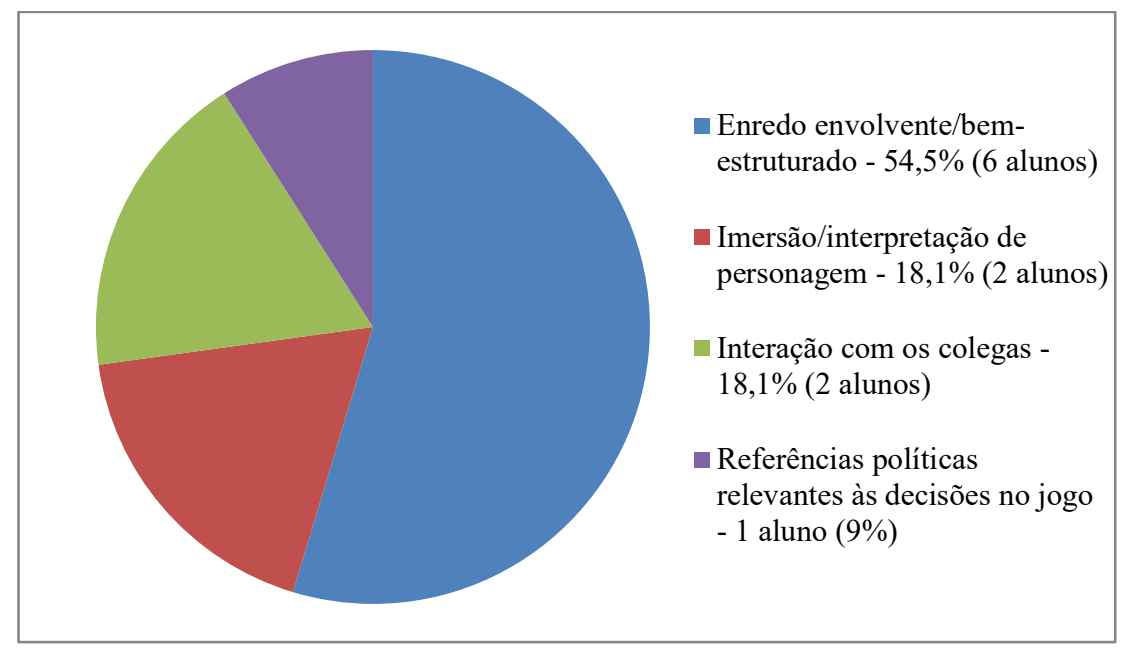

Fonte: Autores.

$\mathrm{Na}$ segunda questão, pediu-se que os alunos assinalassem opções com elementos que acreditavam terem sido trabalhados pelo RPG, podendo marcar quantas quisessem. Foi permitido aos participantes, igualmente, fazerem um comentário específico justificando as opções assinaladas.

GRÁFICO 11 - Das opções disponíveis, marque aquelas (pode ser mais de uma) que indicam os aspectos mais presentes, ou melhor desenvolvidos, no RPG que você jogou.

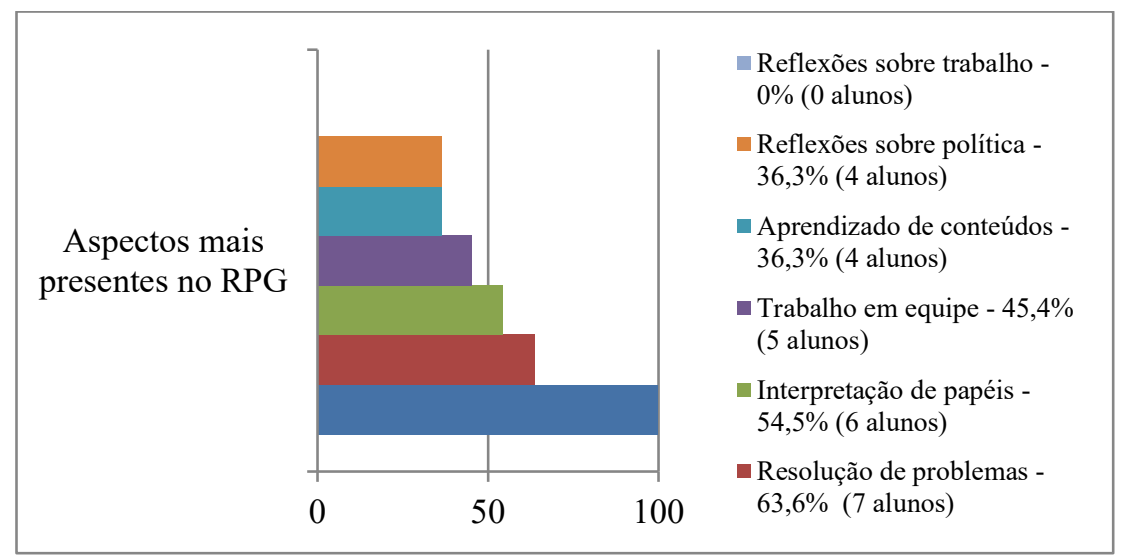

Fonte: Autores.

Dentre os comentários específicos, um aluno (9\%) destacou que a diversão foi proporcionada especificamente pela atividade ocorrer entre amigos. Quanto à "Aprendizado de conteúdos", um aluno (9\%), detalhou ter aprendido sobre linhas de produção e Guerra Fria. É necessário destacar que a opção "Reflexões sobre trabalho", um dos principais objetivos do

participou. Dois alunos do Grupo $02\left(1^{\circ}\right.$ Eletrotécnica e $1^{\circ}$ Informática) jogaram todas as sessões, mas não enviaram os questionários pós-jogo preenchidos ao pesquisador. 
produto educacional, foi a única não assinalada por nenhum dos alunos. Concluímos que, apesar das dinâmicas de sistematização do trabalho e sua exploração presentes nas regras e cenário de jogo, os alunos não as assimilaram num nível explícito - ou então estas acabaram em segundo plano diante das outras impressões causadas pelo jogo. Consideramos mais essa segunda hipótese, pois, pelas respostas das próximas perguntas, percebe-se que os alunos realizaram, sim, reflexões sobre trabalho.

A seguir, na terceira questão, foi indagado quais aspectos do RPG os alunos não gostaram, ou tiveram dificuldades.

GRÁFICO 12 - Comente sobre os aspectos do jogo de RPG que você não gostou e/ou teve dificuldades.

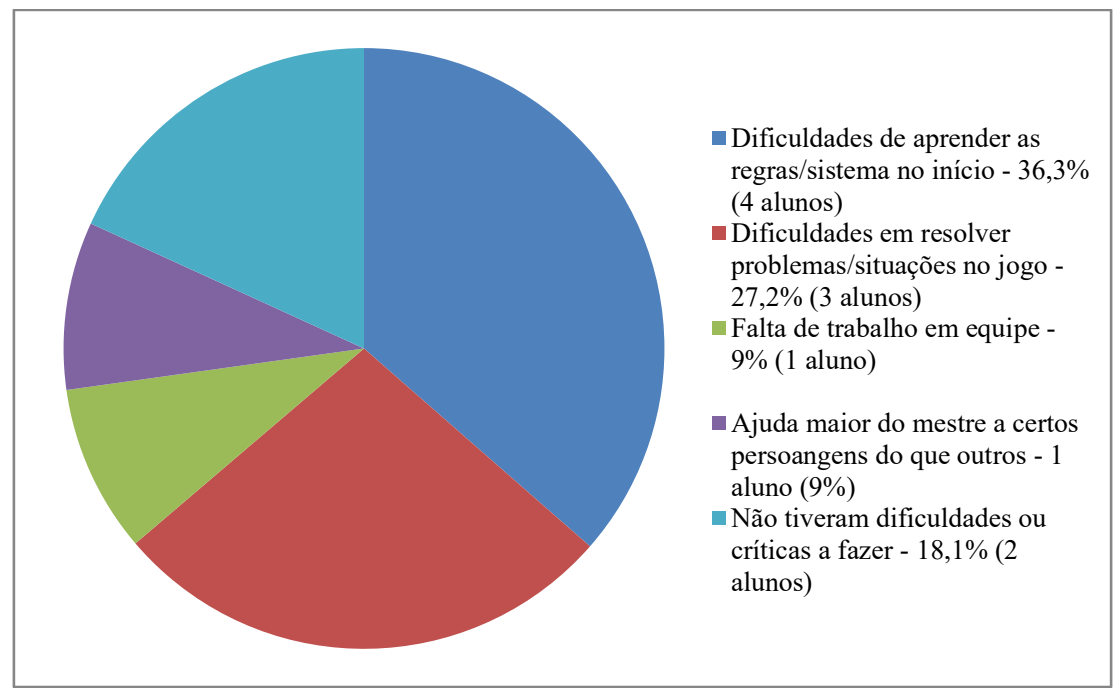

Fonte: Autores.

Concernente à crítica sobre a ajuda maior do mestre a determinados personagens do que a outros (um aluno - 9\%), trata-se de problema ao qual o mestre-professor deve se atentar, com maior chance de ocorrer em mesas de jogo numerosas. É fundamental sempre oferecer um número equilibrado de oportunidades, por sessão, para que cada personagem consiga se destacar por suas habilidades. Caso jogadores iniciantes precisem de mais ajuda que os veteranos no início, deve-se buscar ajudá-los sem que esses jogadores mais experientes sintam-se em segundo plano.

Na quarta pergunta, indagou-se o que os alunos haviam aprendido com o jogo sobre os sistemas de trabalho industrial, como Fordismo ou Toyotismo. 
Mendes, L. F. de O.; Boechat, L. T.; Garzoni, L. de C.

GRÁFICO 13 - O que você aprendeu sobre os sistemas de trabalho industrial (Taylorismo, Fordismo, Toyotismo) no desenvolvimento do jogo?

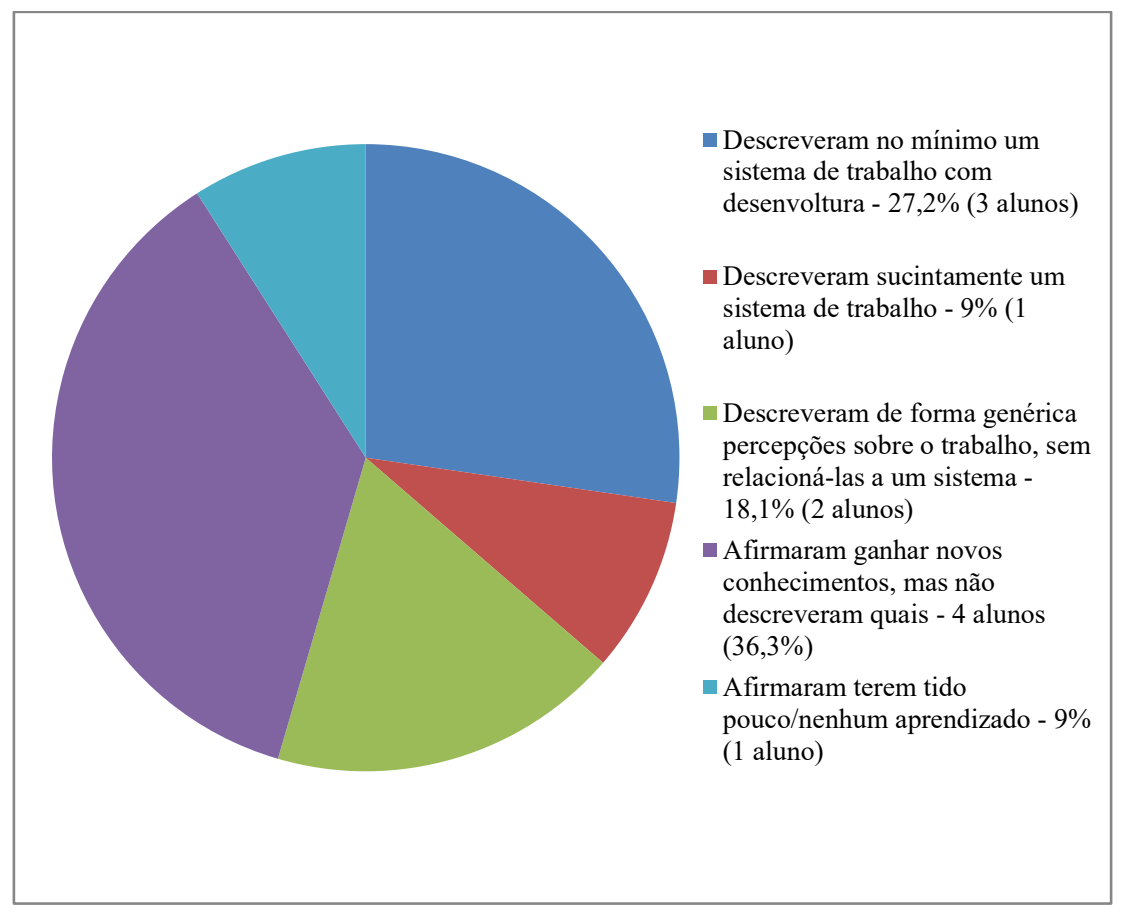

Fonte: Autores.

Dentre os três alunos $(27,2 \%)$ que descreveram com desenvoltura no mínimo um sistema de trabalho industrial em sua resposta, um aluno explicou Toyotismo e Fordismo (apenas confundindo o nome do primeiro com o "Taylorismo"), um aluno dissertou sobre Fordismo, Taylorismo Soviético (identificando-os como similares) e Toyotismo, e um aluno explicou a respeito do Taylorismo Soviético e Stakhanovismo. Desses três alunos, apenas um já havia demonstrado conhecimento prévio dos sistemas no questionário introdutório, e ainda assim de forma mais concisa. O aluno específico que detalhou as duas formas de trabalho soviéticas soubera explicar Fordismo e Toyotismo no questionário inicial - ou seja, o jogo lhe proporcionou conhecimento adicional sobre as duas outras formas que não conhecia. Um aluno (9\%) descreveu sucintamente apenas um sistema de trabalho, no caso o Stakhanovismo, que definiu como "trabalho por fama". Já outros dois alunos $(18,1 \%)$ definiram de modo genérico percepções sobre trabalho adquiridas com o jogo, sem relacioná-las a nenhum sistema específico. As respostas oscilaram entre "Que alguns tinham mais facilidade com maior número de atividades, enquanto outros tinham mais facilidade em apenas um tipo de atividade", e "Divisão do trabalho, especialização e horas bem definidas". 
Mendes, L. F. de O.; Boechat, L. T.; Garzoni, L. de C.

Aqui, observamos que, no tocante ao trabalho industrial soviético, o ganho foi praticamente geral, visto o total desconhecimento dos alunos sobre o tópico demonstrado no questionário inicial. Além disso, um aluno (9\%) destacou explicitamente ter aprendido sobre os sistemas de trabalho a partir do que os personagens conseguiam ou não fazer, gerando a percepção de que as peculiaridades de cada sistema, tornados "classes" no RPG, conseguiram denotar tais diferenças.

O passo seguinte foi questionar os alunos se consideravam tais conhecimentos importantes à sua vida profissional, principalmente em comparação a antes do jogo.

\section{GRÁFICO 14 - Em comparação a antes do RPG, você considera esses conhecimentos importantes para sua vida profissional? Por quê?}

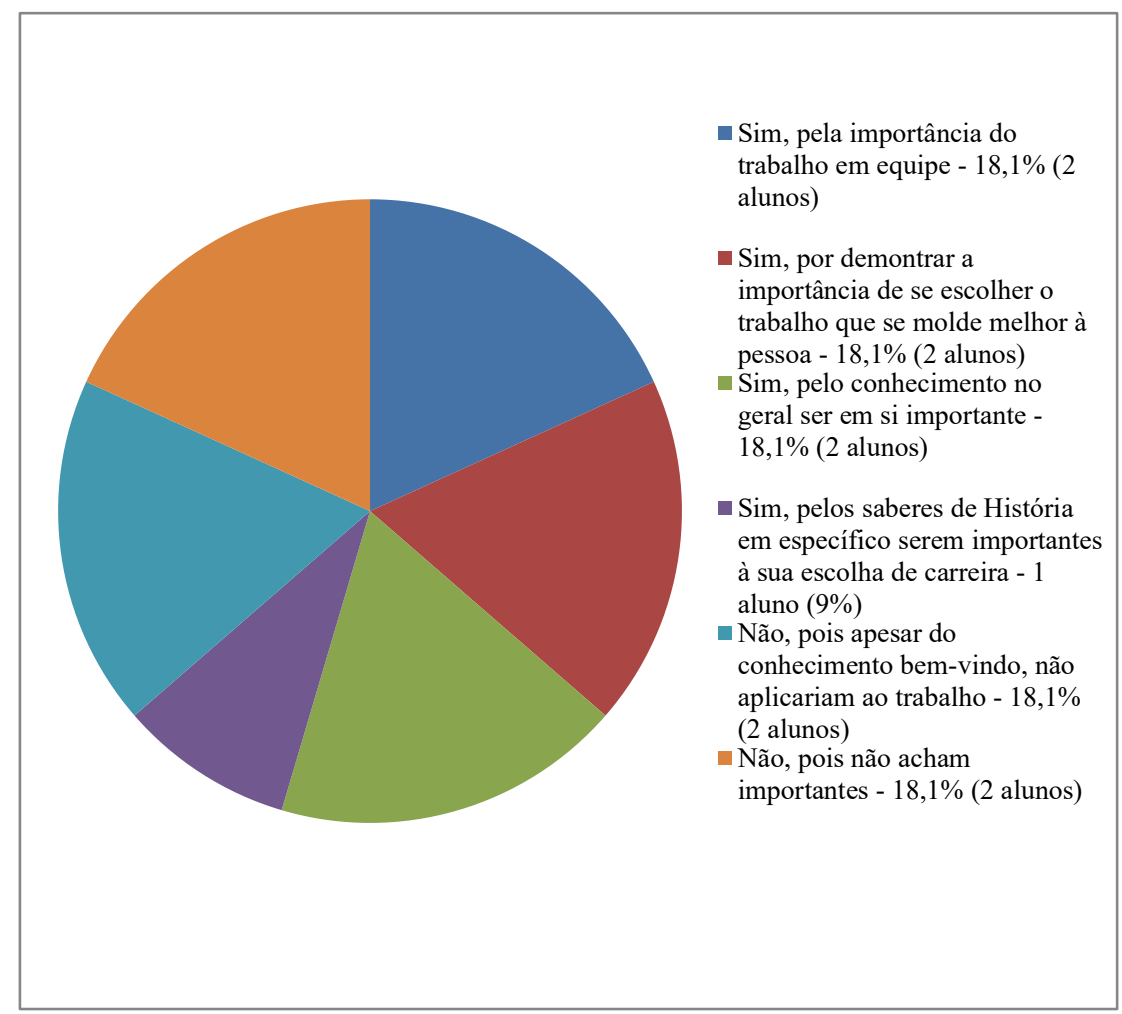

Fonte: Autores.

Ainda dentro desse assunto, a pergunta seguinte indagou se o jogo provocou reflexões sobre os fins do trabalho e seu impacto social. Todos os onze alunos (100\%) afirmaram que sim ou descreveram alguma reflexão. Temos aqui, talvez, o dado mais interessante, e rico, coletado a partir do RPG: 
Mendes, L. F. de O.; Boechat, L. T.; Garzoni, L. de C.

GRÁFICO 15 - O jogo lhe proporcionou reflexões sobre os fins (objetivos) do trabalho, e como ele pode impactar no mundo? Quais?

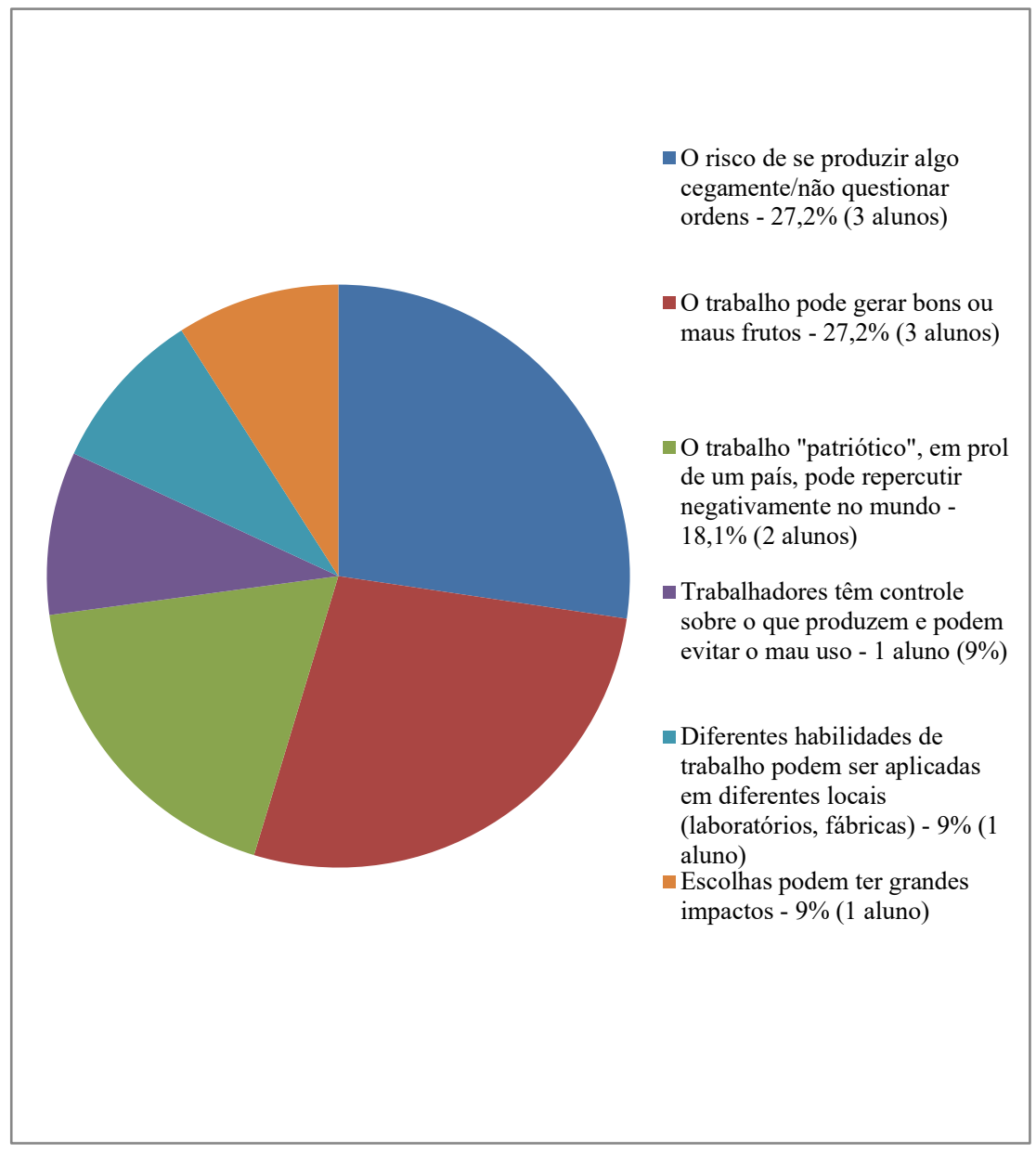

Fonte: Autores.

Tais respostas revelam o acerto do cenário de jogo em sua temática, os operários trabalhando para um suposto fim pacífico e então descobrirem estar fabricando armas de destruição em massa proporcionando relevante reflexão sobre os fins e impactos do trabalho. Além disso, a rivalidade entre EUA e URSS, e a opção quanto aos personagens favorecerem somente um dos lados, condenando o outro à eventual extinção pelos novos armamentos, motivou discussões sobre a produção voltada aos fins bélicos e unilaterais de um país. É relevante analisarmos as respostas apresentadas considerando os diversos alunos que, no questionário inicial, não conseguiam imaginar como seu trabalho impactaria socialmente.

A sétima pergunta questionava a respeito de o jogo ter desconstruído algum clichê prévio que os alunos traziam sobre a Guerra Fria e os dois lados envolvidos - algo pertinente considerando que, como previamente exposto, houve casos de alunos que interpretaram personagens com um viés estereotipado. 
Mendes, L. F. de O.; Boechat, L. T.; Garzoni, L. de C.

GRÁFICO 16 - A experiência do jogo desconstruiu algum clichê ou ideia sem aprofundamento que você tinha sobre Guerra Fria ou Capitalismo x Socialismo? Se sim, qual(is)?

Como ele aprofundou (ou não) sua visão desse período?

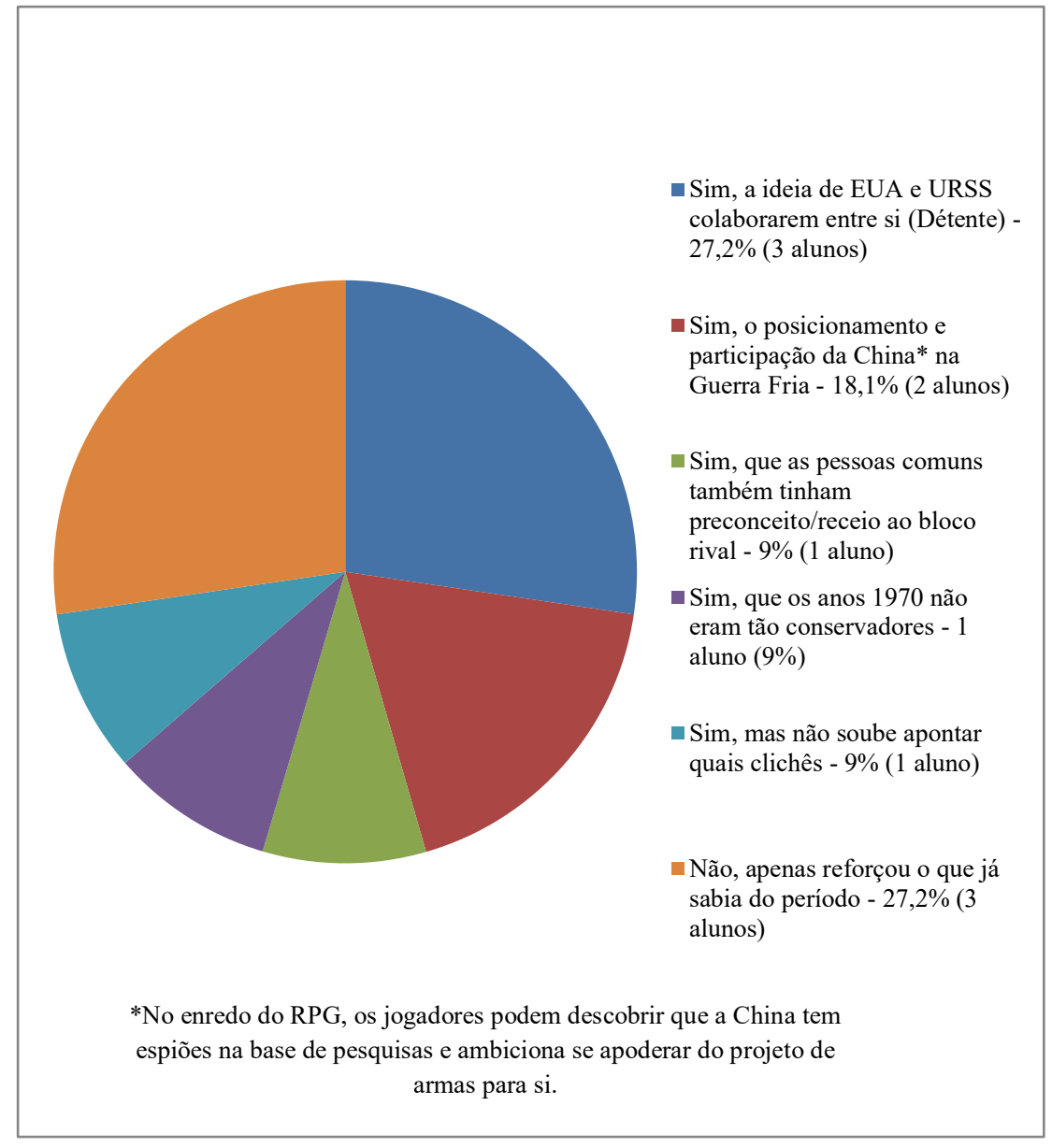

Fonte: Autores.

$\mathrm{Na}$ oitava questão, os alunos foram indagados sobre terem conseguido realizar conexões entre as Ciências Humanas e a área profissionalizante de seus cursos a partir do jogo. Esperava-se que os personagens dos alunos utilizarem perícias correspondentes ao conteúdo estudado na área técnica do Ensino Médio Integrado, tanto em Eletrotécnica quanto em Informática, expusesse a eles como esses conhecimentos podem ser "bem" ou "mal" utilizados no mundo real, a depender de seus fins sociais, políticos ou estratégicos - reflexão concernente às Ciências Humanas. 
Mendes, L. F. de O.; Boechat, L. T.; Garzoni, L. de C.

GRÁFICO 17 - Você conseguiu, através do jogo, estabelecer conexões entre as áreas profissionais de Eletrotécnica e/ou Informática com problemas das Ciências Humanas? Se sim, quais?

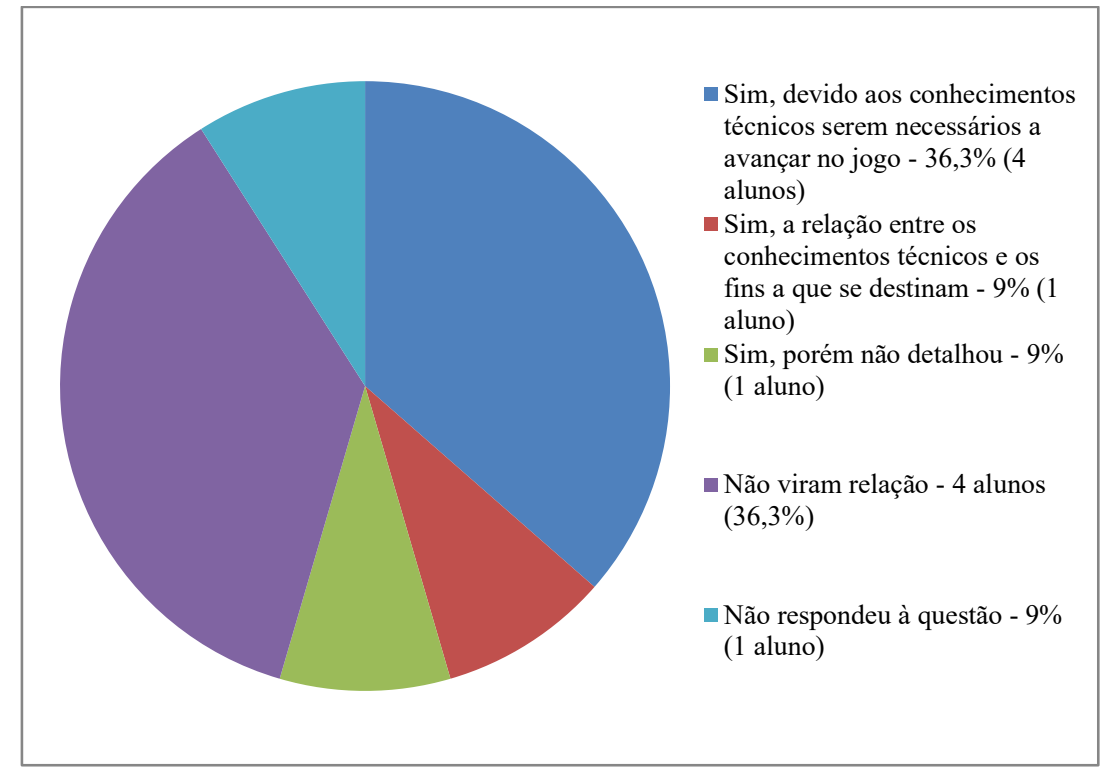

Fonte: Autores.

Seis alunos $(54,5 \%)$ mencionaram que sim. Dos cinco que detalharam sua resposta, quatro $(36,3 \%)$ apontaram que as habilidades específicas da área técnica eram necessárias para avançar no jogo, porém não estabeleceram uma relação entre estas e seus possíveis fins, o que foi apontado somente por um aluno (9\%). Temos que, se a maioria dos alunos conseguiu estabelecer essa conexão no nível do trabalho em geral, não a vislumbrou no vínculo mais específico envolvendo sua formação técnica.

Por fim, foi facultado aos participantes realizar comentários, sugestões ou considerações sobre o jogo. Nove alunos $(81,8 \%)$ responderam.

GRÁFICO 18 - o Comentários, sugestões e considerações finais sobre o RPG e a experiência que ele proporcionou (opcional).

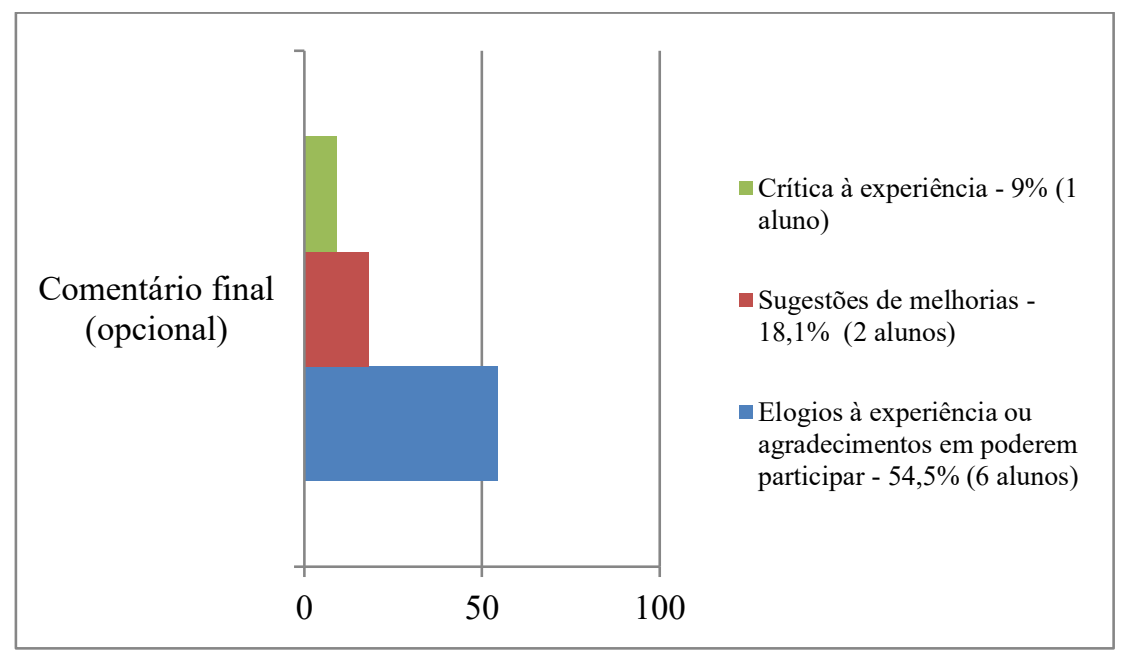

Fonte: Autores. 
Destacando os principais elementos dos comentários, seis alunos $(54,5 \%)$ focaram-se em elogios à experiência ou agradecimentos em poderem participar, dois alunos $(18,1 \%)$ realizaram sugestões de melhorias (no caso, o sistema possibilitar o início de jogo com mais perícias e o mestre não "salvar" tanto os jogadores, por maus resultados nos dados, ao longo da narrativa) e um aluno (9\%) criticou um aspecto da experiência (os conflitos entre jogadores, decorrentes da polarização em grupos), apesar de frisar ter também se divertido.

\section{CONSIDERAÇÕES FINAIS}

No bojo desta pesquisa, diversos pontos importantes à Educação Profissional e Tecnológica (EPT) foram levantados. Primeiramente, a partir da amostra de alunos analisada no IFSULDEMINAS - Campus Poços de Caldas, verificou-se como as Ciências Humanas não estão necessariamente articuladas à área técnica/profissionalizante do Ensino Médio Integrado, reproduzindo uma estrutura advinda da dualidade escolar que separa o domínio sobre a capacidade de trabalho de seu mero exercer, favorecendo a empregabilidade direta, mas não a reflexão humanística e a tomada de consciência sobre o fator social que o trabalho possui. Nota-se como o presente redirecionamento do Ensino Médio aos "itinerários formativos" e a prioridade do ingresso per se no mercado de trabalho podem intensificar essa tendência desagregadora. Segundo os fundamentos filosóficos que permeiam a proposta do Ensino Médio Integrado em instituições como os Institutos Federais (IFs), o currículo deve superar as barreiras entre as disciplinas e tomar o trabalho, e o domínio de seus princípios científicos, como princípio pedagógico, propiciando uma educação realmente integral e omnilateral, no tocante a formar o ser humano em todos os seus aspectos.

A partir dessa visão, o produto educacional consistindo no RPG Trabalho nos Extremos procurou realizar essa articulação, fazendo a disciplina História, através do período da Guerra Fria, dialogar com o mundo do trabalho não só no uso das técnicas de Eletrotécnica e Informática para o avanço dos personagens, mas em como essas técnicas podem causar grandes impactos sociais, inclusive negativos, pelos frutos de sua produção. No objetivo geral de promover essa reflexão - algo que, pelos estudantes analisados, nem sempre foi atingido em suas diferentes etapas de percurso no Ensino Médio Integrado - consideramos que o produto teve sucesso, e é capaz de promover pontes entre as Ciências Humanas e a área profissionalizante, ainda que nem sempre perceptíveis devido à noção de linearidade e ausência de conexão entre os conhecimentos escolares que os alunos tendem a trazer do 
Ensino Fundamental e podem não superar mesmo cursando uma proposta de Ensino Médio que proponha o contrário.

A reflexão mais iminentemente política sugerida pelo RPG, de diálogo entre extremos, não foi atingida de modo relevante nas aplicações realizadas com o produto, os alunos reproduzindo com seus personagens a tendência polarizadora que permeia a sociedade e agregando-se em grupos de visão comum (no caso do jogo, americanos versus soviéticos). Como também dito, parte da interpretação dos personagens, principalmente dos soviéticos, foi pautada por estereótipos prévios trazidos pelos alunos. No caso da discussão geral sobre trabalho, os alunos conseguiram, além de refletir sobre seus impactos, assimilar características que não conheciam sobre suas diferentes sistematizações na indústria, algo favorecido pela mecânica de serem aplicadas como "classes" aos personagens, com características divergentes.

Dadas as circunstâncias de aplicação do produto (por um pesquisador que não constitui professor regular das turmas, num número reduzido de sessões, e de forma independente aos conteúdos curriculares trabalhados em consonância à aplicação), acredita-se que os resultados podem ser mais satisfatórios - tanto na reflexão sobre a polarização, quanto aprofundamento nas questões referentes ao trabalho - com seu uso por um professor regular, ao longo do ano letivo, realizando um trabalho mais intenso de mediação entre os alunos. Devido à atratividade geral exercida pelo jogo sobre os alunos (a ponto de, no Grupo 02, os alunos inclusive terem vindo ao IF para a última sessão no fechamento dos dias letivos, quando já estavam praticamente dispensados de todas as matérias, somente para jogar), envolvê-los em atividades extras a ele relacionadas revela-se um passo profícuo ao educador. Essa mediação ocorreria tanto no sentido de trabalhar os temas abordados no RPG para além das sessões - desde rodas de debate imediatamente depois de cada jogo às próprias aulas expositivas -, até familiarizar os alunos com o sistema de jogo para que eles mesmos possam se tornar mestres e coordenem suas mesas, dividindo uma turma em diversos grupos de aventura.

Isso não apenas permitiria a aplicação do jogo em salas numerosas, mas também tornaria todo o aprendizado envolvido mais intenso e compartilhado. Seguindo as teorias de Vygotsky, o professor atuaria como "andaime de aprendizagem" aos alunos por meio do jogo, e então os capacitaria para também assumirem tal posição junto aos colegas - como ocorreu, nesta pesquisa, em relação aos alunos do último ano já habituados ao RPG auxiliando na familiarização dos ingressantes. Também verificou-se que, pela experiência de sóciointeração promovida pelo jogo, os conceitos sobre mundo do trabalho dos alunos foram reelaborados e, 
Mendes, L. F. de O.; Boechat, L. T.; Garzoni, L. de C.

a partir dessa experiência imaginativa, influenciarão sua consciência quando do real ingresso em suas profissões, principalmente no tocante aos propósitos do que produzirem.

Por fim, espera-se que o produto educacional seja utilizado por outros educadores e adaptado tanto às suas estratégias de ensino em EPT quanto às problemáticas sobre trabalho nas quais seus alunos estiverem inseridos. O professor que aplicar o jogo é bem-vindo a criar suas próprias especializações, com perícias próprias (algo possível seguindo o modelo de regras existente no Livro Básico), para atender a outros cursos de Ensino Médio Integrado ao Técnico. Assim, a ideia é fazer surgirem, na forma de "suplementos de regras" (termo comum a esse tipo de material em RPGs de mesa), novos cenários da Guerra Fria, de autoria de outros educadores, que abordem personagens especialistas em Química, Mecânica, Administração, Enfermagem, Nutrição, Segurança do Trabalho, dentre outras inúmeras áreas de formação e possibilidades. Acreditamos que seu potencial ainda foi pouco explorado e, conjugado a pesquisas abordando as relações entre Ciências Humanas e formação técnica, poderá não só levantar novos dados, mas apontar caminhos a uma educação que se torne a cada dia mais emancipadora.

A atual conjuntura de mudanças no Ensino Médio e o foco na estrita profissionalização, em detrimento da reflexão humanística, exigirá dos educadores não só uma postura de defesa da formação integral, mas iniciativas que a proporcionem na prática. $\mathrm{O}$ rompimento das barreiras entre as áreas propedêutica e técnica, entre o intelectual e o profissional e, principalmente, a conscientização quanto ao mundo do trabalho e suas relações em crescente precarização - problemas levantados por esta pesquisa e que, em variados níveis, inclusive já compõem preocupações dos alunos - devem ser o cerne do Ensino Médio Integrado e constante horizonte para que a conquista de sua implementação não seja perdida.

\section{REFERÊNCIAS BIBLIOGRÁFICAS}

ALVES, Giovanni. Trabalho e mundialização do capital: a nova degradação do trabalho na era da globalização. Londrina: Práxis, 1999.

ANTUNES, Ricardo. Da educação utilitária fordista à da multifuncionalidade liofilizada. Anais da $38^{a}$ Reunião Anual da ANPED, São Luís/MA, UFMA, 2017. Disponível em: < http://38reuniao.anped.org/sites/default/files/resources/programacao/trabalhoencom_38anped _2017_gt11_textoricardoantunes.pdf >. Acesso em: 18/02/2020.

ANTUNES, Ricardo. Os sentidos do trabalho: ensaio sobre a afirmação e a negação do trabalho. São Paulo: Boitempo, 1999.

ARBIX, Glauco. Notas sobre a taylorização soviética do trabalho. In: Revista de Sociologia e Política, Curitiba: UFPR, n. 08, Junho de 1997, pp. 21-30.

AUGUSTIN, A. C. Gestão das fábricas na URSS: é possível um taylorismo socialista?. In: Colóquio Internacional Marx e o Marxismo 2015: Insurreições, passado e presente, 2015, 
Niterói. Anais do Colóquio Internacional Marx e o Marxismo 2015: Insurreições, passado e presente, 2015. Disponível em: <

https://www.academia.edu/9303344/Gest\%C3\%A3o_das_f\%C3\%A1bricas_na_URSS_\%

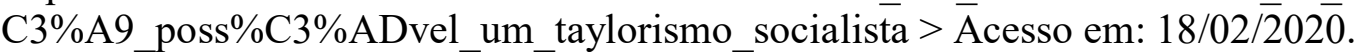

BRASIL, Lei de Diretrizes e B. Lei $n^{\circ}$ 9.394/96, de 20 de dezembro de 1996. Brasília, DF: DOU 23-12-96, 1996.

BRASIL. Decreto n. 5.154, de 23 de julho de 2004. Brasília, DF: DOU 26-7-2004, 2004.

BRASIL. Medida provisória $n^{\circ}$ 746, de 23 de setembro de 2016. Brasília, DF: DOU 23-092016, 2016.

BRUGNAGO, Fabrício; CHAIA, Vera. A nova polarização política nas eleições de 2014: radicalização ideológica da direita no mundo contemporâneo do Facebook. In: Aurora: revista de arte, mídia e política, São Paulo, volume 7, n. 21, Outubro de 2014/Janeiro de 2015, pp. 99-129.

FILTZER, Donald. Labor Discipline, the Use of Work Time, and the Decline of the Soviet System, 1928-1991. In: International Labor and Working-Class History, n. 50, $2^{\circ}$ Semestre de 1996, pp. 9-28.

FRIGOTTO, Gaudêncio; ARAÚJO, Ronaldo Marcos Lima. Práticas pedagógicas e ensino integrado. Revista Educação em Questão. Natal: UFRN, v. 52, n.38. mai/ago 2015, pp. 61-80.

GRAMSCI, Antonio. Os intelectuais. O princípio educativo. In: GRAMSCI, Antonio. Cadernos do Cárcere. $2^{\mathrm{a}}$ Edição, Volume 2, Rio de Janeiro, Civilização Brasileira, 2001.

HOBSBAWN, Eric. A era dos extremos. São Paulo: Companhia das Letras, 1995.

HUIZINGA, Johan. Homo ludens. 4. ed., 1ª reimpressão: São Paulo: Perspectiva, 2000.

LAZAGNA, A.; Lênin e o "taylorismo soviético": uma abordagem crítica. In: Ponto e Virgula, São Paulo: PUC-SP, n. 21, $1^{\circ}$ Semestre de 2017, pp. 36-53.

NOSELLA, Paolo. Ensino médio: em busca do princípio pedagógico. In: Educação e Sociedade, SP. Volume 32, n. 117, Outubro/Dezembro de 2011: pp. 1051-1066.

PEREIRA JÚNIOR, José Nilton Alves; MOREIRA, Eugenio Eduardo Pimentel. Formação integral e dualidade estrutural na política de educação profissional no governo Lula: decreto n. ${ }^{\circ}$ 5.154/04. Educação em Debate, Fortaleza, n. 66-71, Julho/Dezembro 2013, Janeiro/Junho, Julho/Dezembro 2014, Janeiro/Junho, Julho/Dezembro 2015, Janeiro/Junho 2016: pp. 172183.

SAVIANI, Dermeval. O choque teórico da Politecnia. Trab. Educ. Saúde [online]. 2003, vol. 1, n. 1, pp. 131-152. Disponível em: <

http://www.revista.epsjv.fiocruz.br/upload/revistas/r41.pdf > Acesso em 18/02/2020.

SAVIANI, Dermeval. Trabalho e perspectivas de formação dos trabalhadores: para além da formação politécnica. Rev. Bras. Educ. [online]. 2007, vol. 12, n. 34, pp. 137-151. Disponível em: < http://www.scielo.br/pdf/rbedu/v12n34/a11v1234.pdf > Acesso em 18/02/2020.

VAINFAS, Ronaldo [et al.] História 3: ensino médio. São Paulo: Saraiva, 2016.

VASQUES, Rafael Carneiro. As potencialidades do RPG (Role Playing Game) na educação escolar / Dissertação (Mestrado em Educação Escolar) - Universidade Estadual Paulista, Faculdade de Ciências e Letras, Campus de Araraquara. Araraquara, 2008.

VYGOTSKY, Lev Semenovitch. A formação social da mente. Tradução de Grupo de Desenvolvimento e Ritmos Biológicos - Departamento de Ciências Biomédias USP. $4^{\mathrm{a}}$ edição: São Paulo: Martins Fontes, 1991. 
Mendes, L. F. de O.; Boechat, L. T.; Garzoni, L. de C.

VYGOTSKY, Lev Semenovitch. Imaginação e criatividade na infância: ensaio de psicologia. Tradução de João Pedro Fróis. Lisboa, Portugal. Lisboa: Dinalivro, 2012.

VYGOTSKY, Lev Semenovitch. Linguagem, Desenvolvimento e Aprendizagem / Lev Semenovich Vigotskii, Alexander Romanovich Luria, Alex N. Leontiev. Tradução de Maria da Pena Villalobos. 11a edição: São Paulo: Ícone, 2010.

VYGOTSKY, Lev Semenovitch. Pensamento e Linguagem. Ebook. Editor: Ridendo Castig Mores, 2001. Disponível em: < http://www.ebooksbrasil.org/adobeebook/vigo.pdf $>$ Acesso em $18 / 02 / 2020$. 